\title{
Quantitative proteomic analysis
} of pancreatic cyst fluid proteins associated with malignancy in intraductal papillary mucinous neoplasms

Misol Do ${ }^{1 \dagger}$, Dohyun Han ${ }^{4 \dagger}$, Joseph Injae Wang ${ }^{2}$, Hyunsoo Kim² ${ }^{2}$ Wooil Kwon ${ }^{3}$, Youngmin Han ${ }^{3}$, Jin-Young Jang ${ }^{3^{*}}$ and Youngsoo Kim ${ }^{1,2^{*}}$ (D)

\begin{abstract}
Background: The application of advanced imaging technologies for identifying pancreatic cysts has become widespread. However, accurately differentiating between low-grade dysplasia (LGD), high-grade dysplasia (HGD), and invasive intraductal papillary mucinous neoplasms (IPMNs) remains a diagnostic challenge with current biomarkers, necessitating the development of novel biomarkers that can distinguish IPMN malignancy.

Methods: Cyst fluid samples were collected from nine IPMN patients (3 LGD, 3 HGD, and 3 invasive IPMN) during their pancreatectomies. An integrated proteomics approach that combines filter-aided sample preparation, stage tip-based high-pH fractionation, and high-resolution MS was applied to acquire in-depth proteomic data of pancreatic cyst fluid and discover marker candidates for IPMN malignancy. Biological processes of differentially expressed proteins that are related to pancreatic cysts and aggressive malignancy were analyzed using bioinformatics tools such as gene ontology analysis and Ingenuity pathway analysis. In order to confirm the validity of the marker candidates, 19 cyst fluid samples were analyzed by western blot.

Results: A dataset of 2992 proteins was constructed from pancreatic cyst fluid samples. A subsequent analysis found 2963 identified proteins in individual samples, 2837 of which were quantifiable. Differentially expressed proteins between histological grades of IPMN were associated with pancreatic diseases and malignancy according to ingenuity pathway analysis. Eighteen biomarker candidates that were differentially expressed across IPMN histological grades were discovered-7 DEPs that were upregulated and 11 that were downregulated in more malignant grades. HOOK1 and PTPN6 were validated by western blot in an independent cohort, the results of which were consistent with our proteomic data.
\end{abstract}

Conclusions: This study demonstrates that novel biomarker candidates for IPMN malignancy can be discovered through proteomic analysis of pancreatic cyst fluid.

Keywords: Pancreatic cyst fluid, Intraductal papillary mucinous neoplasm (IPMN), IPMN dysplasia, Biomarker candidates, LC-MS/MS

\footnotetext{
*Correspondence: jangjy4@snu.ac.kr; biolab@snu.ac.kr

${ }^{\dagger}$ Misol Do and Dohyun Han contributed equally to this work

2 Department of Biomedical Engineering, Seoul National University

College of Medicine, 28 Yeongeon-dong, Seoul 110-799, Korea

${ }^{3}$ Department of Surgery, Seoul National University College of Medicine,

28 Yeongeon-dong, Seoul 110-799, Korea

Full list of author information is available at the end of the article
}

(c) The Author(s) 2018. This article is distributed under the terms of the Creative Commons Attribution 4.0 International License (http://creativecommons.org/licenses/by/4.0/), which permits unrestricted use, distribution, and reproduction in any medium, provided you give appropriate credit to the original author(s) and the source, provide a link to the Creative Commons license, and indicate if changes were made. The Creative Commons Public Domain Dedication waiver (http://creativecommons.org/ publicdomain/zero/1.0/) applies to the data made available in this article, unless otherwise stated. 


\section{Background}

Intraductal papillary mucinous neoplasms (IPMNs) are precancerous lesions that grow in the pancreatic ducts and are characterized by papillary growth of the ductal epithelium. The production of thick mucinous fluid, another hallmark of IPMNs, causes cystic dilation and can progress into pancreatic ductal adenocarcinoma [14]. Depending on the malignancy, IPMN is classified as low-grade dysplasia (LGD), intermediate-grade dysplasia (IGD), high-grade dysplasia (HGD), and invasive IPMN. According to the official guidelines for managing pancreatic IPMN, only patients with HGD or invasive IPMN require surgery, because they are at higher risk of their disease developing into cancer [5]. Milder forms of IPMN can be managed with active surveillance and do not warrant surgical intervention. However, current methods for assessing the histological grades of IPMNs are unreliable, and as a result, patients with milder IPMN are often subjected to unnecessary operations [6-10].

In clinical practice, MRI and CT scans, cytological examination of cyst fluid, measurement of tumor markers such as carcinoembryonic antigen (CEA) and carbohydrate antigen 19-9 (CA 19-9), and analysis of GTPase Kras (KRAS) and guanine nucleotide-binding protein alpha subunit (GNAS) mutations are used to categorize patients with pancreatic cysts [6, 7, 10-16]. Features of pancreatic images in MRI or CT scans are generally used to assess the potential malignancy of cysts but have low diagnostic accuracy-up to $40 \%$ of neoplastic cysts are misdiagnosed as pseudocysts, and the overall accuracy ranges from 20 to $80 \%$ [17-19]. Cytological examination of pancreatic cyst fluid is an alternative approach, but it has difficulties in identifying the existence of malignancy when sufficient sample volumes are unavailable [16, 20-23]. Differentiating mucinous cysts from other cystic lesions by measuring carcinoembryonic antigen levels in cyst fluid has relatively low accuracy (79\% sensitivity, $73 \%$ specificity) $[17,24]$. Similarly, as shown by Frossard et al. [25], CA 19-9, a pancreatic cancer marker, also performs poorly in distinguishing mucinous cysts and other lesions, with $15 \%$ sensitivity and $81 \%$ specificity [16]. Analyzing GNAS mutations are only applicable for samples that are acquired during the early stages of IPMN $[20,23,26,27]$. The general consensus is that existing methods for diagnosing IPMN histological grades are imprecise and unreliable, even when used in tandem [6, $7,10,16,17,20]$.

Because pancreatic cyst fluid contains secreted proteins from tumor cells at higher proportions, several groups, such as Poersch et al. [28], have concluded that it is a better experimental model of IPMN histological grades than serum and plasma [16, 29-32]. Consequently, pancreatic cyst fluid has been widely favored in recent research on IPMN, because it is obtainable by endoscopic ultrasoundguided fine needle aspiration biopsy, which is minimally invasive $[6,25,33]$. Many studies have focused on discovering protein markers that differentiate mucinous from nonmucinous cyst fluid and cyst fluid that is related to IPMN dysplasia, based on DNA methylation and telomerase activity, as demonstrated by Hata et al. [20]. Diagnosing histological grades of IPMN using pancreatic cyst fluid by proteomic analysis is a relatively unexplored area $[6,7,20,34,35]$. Thus, the IPMN dysplasia proteome has not been characterized extensively.

Cuoghi et al. [36] performed a cursory profiling study of the proteomic patterns of pancreatic cyst fluids from various cystic lesions, including IPMN, MCN, serous cystadenomas, pancreatic neuroendocrine tumors, and pseudocysts, identifying $220-727$ proteins in these fluids. Specifically, 243 proteins were identified in the IPMN groups. Gbormittah et al. [37] characterized glycoproteins and nonglycoproteins in mucinous and nonmucinous pancreatic cyst fluid to identify DEPs as potential biomarker targets. They found 230 proteins in mucinous subtypes and 290 proteins in nonmucinous subtypes; the DEPs between mucinous and nonmucinous cyst fluid were associated with lipid metabolism, energy metabolism, and stress responses. These studies were unable to determine the IPMN histological grades, merely differentiating between mucinous and nonmucinous cyst fluid. These recent studies demonstrate that the current cyst fluid proteome lacks the coverage to extrapolate meaningful conclusions on the molecular and biological activities of the identified proteins, which ultimately impedes our understanding of IPMN histology in terms of proteomic differences and biological functions.

In this report, we aimed to comprehensively identify pancreatic cyst fluid proteins and discover differentially expressed proteins in accordance with histological grades of IPMN. Recently, we reported a platform for in-depth profiling of pancreatic cyst fluid [38]. Using this platform, the protein expression patterns of pancreatic cyst fluid were analyzed on a high-resolution mass spectrometer to discover potential biomarkers of IPMN histological grades. Subsequently, we validated some of the 18 candidate markers by western blot. We report here that pancreatic cyst fluid is a valuable source for biomarker studies as it contains putative markers related to IPMNs and that bioinformatics analyses using identified proteins of cyst fluid enhance our understanding of IPMNs at the molecular level. We ultimately intend to discover marker candidates that can help patients avoid unnecessary operations. 


\section{Methods}

\section{Clinical samples}

Cyst fluid samples were collected from 9 IPMN patients during their pancreatectomies at Seoul National University Hospital (Seoul, South Korea) from April 2013 to December 2015. At least $200 \mu \mathrm{L}$ of cyst fluid was aspirated from each patient. The samples were then snap-frozen in liquid nitrogen and stored at $-80{ }^{\circ} \mathrm{C}$. All patients consented to participation in the study in accordance with Institutional Review Board guidelines (IRB No. 1301-095-458). IPMN samples were divided into lowgrade dysplasia (LGD, $\mathrm{n}=3$ ), high-grade dysplasia (HGD, $\mathrm{n}=3)$, and invasive $\operatorname{IPMN}(\mathrm{n}=3)$.

\section{Pancreatic cyst fluid protein sample preparation}

Each pancreatic cyst fluid sample was transferred to an Eppendorf tube. Viscous samples that could not be pipetted were sonicated briefly (Sonics and Materials Inc., USA) to remove the mucus. All samples were centrifuged at $15,000 \mathrm{rpm}$ for $20 \mathrm{~min}$ at $4{ }^{\circ} \mathrm{C}$, and the supernatant was placed into a new tube. The protein concentration was estimated using a BCA reducing agent compatibility assay kit (Thermo Scientific, Rockford, IL, USA). Equal portions of each sample were pooled to create a peptide library from $600 \mu \mathrm{g}$ of proteins. One hundred micrograms of individual protein samples were used for labelfree quantification. Cold acetone (Sigma-Aldrich, USA) was added to the supernatant to the ratio of $5: 1(\mathrm{v} / \mathrm{v})$ to precipitate the proteins. The mixture was vortexed gently and incubated overnight at $-20{ }^{\circ} \mathrm{C}$. The precipitate was centrifuged for $10 \mathrm{~min}\left(15,000 \mathrm{rpm}\right.$ at $\left.4{ }^{\circ} \mathrm{C}\right)$, and the supernatant was carefully decanted, after which $500 \mu \mathrm{L}$ cold acetone was added to the pellet. After this wash step, the pellet was centrifuged for $10 \mathrm{~min}(15,000 \mathrm{rpm}$ at $4{ }^{\circ} \mathrm{C}$ ). The remaining acetone was poured off, and the pellet was air-dried for $2 \mathrm{~h}$.

\section{Protein digestion and desalting}

The pellet was dissolved in $30 \mu \mathrm{L}$ of lysis buffer (4\% SDS, $0.1 \mathrm{M}$ DTT, $0.1 \mathrm{M}$ Tris-Cl, $\mathrm{pH}$ 7.4). The mixture was gently vortexed and boiled for $30 \mathrm{~min}$ at $95{ }^{\circ} \mathrm{C}$. The boiled mixture was then transferred through a $30-\mathrm{kDa}$ cutoff filter (Amicon ${ }^{\circledR}$ Ultra, Millipore, USA) with $300 \mu \mathrm{L} 8 \mathrm{M}$ urea (8 M Urea, $0.1 \mathrm{M}$ Tris-Cl, $\mathrm{pH} 8.5$ ) and centrifuged $\left(14,000 \mathrm{~g}, 15 \mathrm{~min}, 20^{\circ} \mathrm{C}\right)$. This filtration step was repeated twice to dilute and lower the SDS concentration. Next, $200 \mu \mathrm{L} 50 \mathrm{mM}$ IAA (50 mM IAA, $8 \mathrm{M}$ urea, $0.1 \mathrm{M}$ Tris$\mathrm{Cl}, \mathrm{pH}$ 8.5) was added to each sample and incubated for $1 \mathrm{~h}$ at $25^{\circ} \mathrm{C}$. Each sample was then centrifuged and washed twice with $300 \mu \mathrm{L} 8 \mathrm{M}$ urea and then three times with $300 \mu \mathrm{L} 40 \mathrm{mM}$ ammonium bicarbonate (ABC).

After the samples were centrifuged, $100 \mu \mathrm{L} 40 \mathrm{mM}$ $\mathrm{ABC}$ and $0.1 \mu \mathrm{g} / \mu \mathrm{L}$ trypsin (at a trypsin:sample ratio of
$1: 80, \mathrm{wt} / \mathrm{wt}$ ) were added to each sample and incubated for $18 \mathrm{~h}$ at $37^{\circ} \mathrm{C}$. Next, the filters (nine individual samples, one pooled sample) were transferred to new collection tubes, which were centrifuged after $100 \mu \mathrm{L} 40 \mathrm{mM}$ $\mathrm{ABC}$ was added. Fifty microliters $\mathrm{NaCl}$ was added to each individual sample, and $50 \mu \mathrm{L}$ water was added to the pooled sample. The pooled sample underwent an additional digestion step $[39,40]$. Again, the filter unit was transferred to a new tube and centrifuged after $200 \mu \mathrm{L}$ $8 \mathrm{M}$ urea was added. Then, the unit was centrifuged twice with $300 \mu \mathrm{L} 40 \mathrm{mM} \mathrm{ABC}$. One-tenth of the concentration of trypsin that was used in the first digestion step was added with $100 \mu \mathrm{L} 40 \mathrm{mM} \mathrm{ABC}$, and the unit was incubated for $18 \mathrm{~h}$ at $37^{\circ} \mathrm{C}$. Next, the filter was transferred to another tube, and the peptides were collected by sequential centrifugation with $100 \mu \mathrm{L} 40 \mathrm{mM}$ ABC and $50 \mu \mathrm{L} 0.5 \mathrm{M} \mathrm{NaCl}$.

Prior to acidification and desalting, all tryptic peptides were measured by tryptophan fluorescence assay to determine the volume that was required to extract the same amount of peptides from each sample [41]. The equalized amounts of peptides were then set aside for label-free quantification. The measured peptides were acidified with $10 \mu \mathrm{L} 10 \%$ TFA and desalted with homemade C18-StageTip columns as described [42]. The desalted peptides were then lyophilized on a speed-vacuum centrifuge and stored at $-80^{\circ} \mathrm{C}$.

\section{Peptide fractionation by high-pH reverse phase fractionation}

To increase the number of identified proteins, the pooled cyst fluid sample was fractionated using two methods: modified stage-tip-based high-pH peptide fractionation $[43,44]$ and offline HPLC high-pH fractionation on an Agilent 1260 Bio-inert. For stage-tip fractionation, half of the lyophilized peptides were dissolved in $200 \mu \mathrm{L}$ of loading buffer $(15 \mathrm{mM}$ ammonium hydroxide solution, $\mathrm{pH}$ 10 , and $2 \%$ acetonitrile) and separated on a pipette-based C18 RP microcolumn. The column was constructed by plugging the bottom of a $200 \mu \mathrm{L}$ transparent pipette tip with C18 Empore disk membrane (3 M, Bracknell, UK) and packing the tip with POROS $20 \mathrm{R} 2$ resin. The plugged tip was rinsed three times with $100 \mu \mathrm{L} 100 \%$ methanol and then three times with $100 \mu \mathrm{L} \mathrm{100 \%}$ acetonitrile $(\mathrm{ACN})$. The column was then conditioned with $100 \mu \mathrm{L}$ of loading buffer using a syringe. The peptides were loaded onto the column at $\mathrm{pH} 10$. An ACN gradient of $2,5,7.5,10,12.5,15,17.5,20,22.5,25,27.5,30,32.5$, $35,40,50,60,70,80$, and $100 \%$ was used to elute 20 fractions, which were collected into six tubes discontinuously to distribute eluents of varying hydrophobicity. These six fractions were lyophilized in a speed-vacuum centrifuge and stored at $-80^{\circ} \mathrm{C}$. 
The remaining half of the lyophilized peptides was dissolved in $80 \mu \mathrm{L}$ of loading buffer $(15 \mathrm{mM}$ ammonium hydroxide in water, $\mathrm{pH} 10)$. The peptides were loaded onto the column, and 96 (2 mL Square Collection Plate, Waters, UK) fractions were eluted by applying an ACN gradient $(\mathrm{pH} \mathrm{10,5-35 \% )} \mathrm{for} 40 \mathrm{~min}$ at a flow rate of $0.2 \mathrm{~mL} / \mathrm{min}$ and washing the column with $90 \% \mathrm{ACN}$ for $10 \mathrm{~min}$ at $0.2 \mathrm{~mL} / \mathrm{min}$. The ACN gradient was established by mixing varying proportions of solution $\mathrm{A}(0.1 \%$ formic acid in HPLC-grade distilled water) and solution B $(0.1 \%$ formic acid in $\mathrm{ACN}$ ). The 96 fractions were concatenated according to the column number of the plate to produce 12 pooled fractions. The resulting 12 tubes were lyophilized in a speed-vacuum centrifuge and stored at $-80^{\circ} \mathrm{C}$.

\section{LC-MS/MS analysis}

The peptide samples were analyzed using an LC-MS/MS configuration, comprising an Easy-nLC 1000 (Thermo Fisher Scientific, Waltham, MA, USA) that was coupled to a $\mathrm{Q}$ Exactive mass spectrometer with a nanoelectrospray ion source (Thermo Fisher Scientific, Waltham, MA, USA), per our established protocol [38, 44, 45]. Peptides were separated on a 2-column system that was composed of a trap column $(75 \mu \mathrm{m}$ I.D. $\times 2 \mathrm{~cm}, \mathrm{C} 183.0 \mu \mathrm{m}$, $100 \AA)$ and an analytical column $(50 \mu \mathrm{m}$ I.D. $\times 15 \mathrm{~cm}$, C18 $3.0 \mu \mathrm{m}, 100 \AA$ ).

Fractionated peptides were subjected to an ACN gradient (6-60\%) for $235 \mathrm{~min}$. The gradient was created by mixing solvent $\mathrm{A}(2 \% \mathrm{ACN}$ and $0.1 \% \mathrm{v} / \mathrm{v}$ formic acid) and solvent B ( $100 \%$ acetonitrile and $0.1 \% \mathrm{v} / \mathrm{v}$ formic acid) at various proportions. The spray voltage was set to $2.0 \mathrm{kV}$ in positive ion mode, and the temperature of the heated capillary was set to $320^{\circ} \mathrm{C}$. Mass spectra were acquired in data-dependent mode by top 20 method on an Orbitrap analyzer with a mass range of $350-1700 \mathrm{~m} / z$ and a resolution of 70,000 at $m / z 200$. HCD scans were acquired at a resolution of 17,500. HCD peptide fragments were acquired at a normalized collision energy (NCE) of 27. The maximum ion injection time for the survey scan and MS/MS scan was 20 and $80 \mathrm{~ms}$, respectively. All samples were analyzed in three technical replicates.

\section{Raw data search}

The MS data from the Q Exactive were processed in MaxQuant (version 1.5.5.1 with built-in Andromeda search engine) [46]. Precursor MS signal intensities were determined, and HCD MS/MS spectra were de-isotoped and filtered, such that only the 20 most abundant fragments per $100 \mathrm{~m} / z$ range were retained. Protein groups were identified by searching the MS and MS/MS data of the peptides against the Uniprot human database (2014 December, 88,717 entries). Both the forward and reverse amino acid sequences were taken into account when calculating the false discovery rate (FDR). Following established target-decoy search procedures [47], search results were filtered at $\mathrm{FDR}<1 \%$ for identifying peptides, modification sites, and proteins. The search was conducted in digestion mode trypsin/P, which assumes cleavage at carboxyl sides of lysine and arginine, including cases where the subsequent residue is a proline.

The following parameters were used in the database search: precursor and HCD fragment mass tolerances of 6 and $20 \mathrm{ppm}$, respectively; tolerance of up to two missed cleavages; carbamidomethylation of cysteine as a fixed modification; and oxidation of Met and acetylation of protein $\mathrm{N}$-term as variable modifications. The minimum peptide length was set to six residues. Peptides were assigned to protein groups by the principle of parsimony [48-50]. The principle is applied to derive the smallest list of probable protein groups that adequately represent the identified peptides, which reduces sequence redundancy issues. All proteomics data in this report have been deposited in the ProteomeXchange Consortium (http:// proteomecentral.proteomexchange.org/) through the PRIDE partner repository: dataset identifier PXD008302 $[51,52]$.

\section{Label-free quantification and statistical analysis}

Label-free quantification (LFQ) and statistical analysis were performed in MaxQuant (version 1.5.5.1) and Perseus (version 1.5.8.5), respectively, according to our previous studies $[43,45]$. Protein abundance was obtained from LFQ intensity values. LFQ intensity was calculated as described by the equation by Cox et al. [53]. Each of the three histological groups in this study had three biological replicates, which in turn had three technical replicates each. Thus, a total of 9 LFQ intensity values exist per histological group (three biological replicates $\times$ three technical replicates). LFQ intensity values greater than zero were deemed valid. Proteins with at least six valid values within a histological group were used in statistical analysis for label-free quantification. This criterion was used to reduce the possibility of analyzing proteins that are nonspecific to histological grades. After $\log 2-$ transformation of protein intensities, the missing values were replaced with expected intensities based on the normal distribution (imputation width $=0.3$, shift $=1.8$ ) of log2-transformed LFQ intensities [43]. Student's $t$ test was applied to the preprocessed dataset of matched proteins to detect DEPs across grades of IPMN dysplasia. The comparative pairs for the statistical analysis were LGD versus HGD (comparison 1), HGD versus invasive IPMN (comparison 2), and LGD versus invasive IPMN (comparison 3). A Benjamini-Hochberg FDR threshold of 0.05 was applied to each pair to find significantly changed proteins. Subsequently, the expression patterns 
of overlapping DEPs across two or more pairs were analyzed to screen for biomarker candidates. DEPs that had expression patterns that varied based on the malignancy of IPMN were selected as final biomarker candidates. The resulting DEPs were subjected to hierarchical clustering in Perseus (version 1.5.8.5) with the following parameters: Euclidean distance, average linkage, the number of clusters of 100 , maximal number of iterations of 10 , the number of restarts of 1 , and $\mathrm{k}$-means preprocessing prior to clustering.

\section{Bioinformatics analysis}

The gene ontologies (GOs) of all DEPs were annotated using the DAVID bioinformatics resource tool (https:// david.ncifcrf.gov/) and the UniprotKB database (http:// www.uniprot.org/). The GO analysis included information on biological process (BP), cellular component (CC), and molecular function (MF). Pathway analysis was performed using the KEGG database (http://www. genome.jp/kegg/). Secretory protein prediction and functional annotation were performed using SignalP 4.1 (http://www.cbs.dtu.dk/services/SignalP/), SecretomeP 2.0 (http://www.cbs.dtu.dk/services/SecretomeP/), and TMHMM, server 2.0 (http://www.cbs.dtu.dk/services/ TMHMM/). Ingenuity pathway analysis (IPA) was used to conduct functional analysis (Ingenuity Systems, http:// www.ingenuity.com/). The plasma proteome database (PPD) was used to confirm the association between the proteins that were identified in human plasma and the proteins that were identified in this study $[54,55]$. The proteins that were identified in our dataset were crossreferenced with mRNA and protein expression in pancreatic sections in the Human Protein Atlas (http://www. proteinatlas.org/).

\section{Western blot analysis}

A total of 19 pancreatic cyst fluid samples-10 LGD, 4 HGD, and five invasive IPMN-were used to validate the candidate markers. Equal volumes of a pooled cyst fluid sample were loaded onto each gel to correct for the intensity of the blots. Pancreatic cyst fluid samples were mixed with $5 \times$ SDS loading dye $(250 \mathrm{mM}$ Tris $-\mathrm{Cl}$, pH 6.8, 10\% SDS, 50\% glycerol, 0.5 M DTT, 0.1\% bromophenol blue). Proteins ( $40 \mu \mathrm{g}$, as measured by BCA assay) were separated on 10\% SDS-PAGE gels and transferred to polyvinylidene fluoride (PVDF) membranes (HybondP, GE Healthcare, Pittsburgh, PA, USA). The membranes were stained with Ponceau S dye (P7170, Sigma-Aldrich, USA), blocked with 5\% BSA for $2 \mathrm{~h}$ at RT, and incubated overnight at $4{ }^{\circ} \mathrm{C}$ with the following primary antibodies: rabbit monoclonal anti-HOOK1 (ab150397, Abcam, Cambridge, UK) at 1:250, mouse monoclonal antiPTPN6 (sc-7289, Santa Cruz Biotechnology, USA) at
1:1000, and mouse polyclonal anti-SERPINA5 (ab67368, Abcam, Cambridge, UK) at 1:100. The membranes were then washed five times with Tris-buffered saline and Tween-20 (TBS-T) before being incubated with the following HRP-conjugated secondary antibodies: antirabbit (ab6721, Abcam, Cambridge, UK) at 1:1000 and anti-mouse (ab6789, Abcam, Cambridge, UK) at 1:2500 for $2 \mathrm{~h}$ at RT. The membranes were developed with ECL solution (West-Q chemiluminescent substrate Kit-plus, GenDEPOT, Barker, TX, USA), and the signals were visualized on an LAS-4000 (Fujifilm, Japan).

\section{Results}

\section{Clinical sample characterization}

Pancreatic cyst fluid samples from nine patients were classified into three groups: LGD $(n=3), \operatorname{HGD}(n=3)$, and invasive IPMN $(n=3)$. The samples did not differ significantly in composition, with the exception of serum CEA level and CA 19-9 concentration measured by chemiluminescent microparticle immunoassay and cyst size (Table 1). The invasive IPMN patient group had the highest average CEA and CA19-9 concentrations at $7.67 \pm 7.06$ and $117.17 \pm 142.78 \mathrm{mg} / \mathrm{L}$, respectively. CEA and CA19-9 levels were generally higher in the more severe forms of IPMN. The average CEA concentration was approximately 3-fold higher for HGD than LGD subjects and 7-fold higher in invasive IPMN versus LGD. In addition, the average CA19-9 level was approximately 2 -fold and 30-fold greater for these comparisons. Our samples were consistent with several publications that have reported that malignant cysts tend to be larger, as evidenced by our invasive IPMN samples $(6.63 \pm 3.74 \mathrm{~cm})$ being twice as large as LGD $(2.93 \pm 0.54 \mathrm{~cm})$ and HGD $(2.50 \pm 0.41 \mathrm{~cm})$ samples on average $[5,56-59]$.

\section{In-depth analysis of pancreatic cyst fluid}

The overall scheme of the study was based on a proteomic platform of cyst fluids that we established earlier [38]. In this study, nine individual pancreatic cyst fluid samples of various types [LGD $(n=3), \operatorname{HGD}(n=3)$, and invasive IPMN $(n=3)]$ were used for label-free quantification. All samples were centrifuged, and only the supernatant was used. The same portions of individual samples were pooled and fractionated to generate a peptide library, which increased the depth of the identified proteins. In contrast, the nine individual samples were not fractionated. After a series of sample preparation steps, LC-MS/MS analysis was performed on a $\mathrm{Q}$ Exactive mass spectrometer. The MS data were processed in MaxQuant (version 1.5.5.1), and the statistical analysis was performed in Perseus (version 1.5.8.5) (Fig. 1; Additional file 1: Fig. S1a). 
Table 1 Demographic and clinical characteristics of the study population used in the label-free quantification

\begin{tabular}{|c|c|c|c|}
\hline \multirow[t]{2}{*}{ Group } & \multicolumn{3}{|c|}{ Pancreatic cyst fluids } \\
\hline & $\begin{array}{l}\text { LGD } \\
(n=3)\end{array}$ & $\begin{array}{l}\mathrm{HGD} \\
(n=3)\end{array}$ & $\begin{array}{l}\text { Invasive IPMN } \\
(n=3)\end{array}$ \\
\hline Age (years) & $69.00 \pm 1.41$ & $66.33 \pm 8.58$ & $58.33 \pm 11.09$ \\
\hline \multicolumn{4}{|l|}{ Gender } \\
\hline Male & 1 & 2 & 1 \\
\hline Female & 2 & 1 & 2 \\
\hline \multicolumn{4}{|l|}{ Gland type } \\
\hline Gastric & 2 & 2 & 1 \\
\hline Intestinal & 0 & 1 & 1 \\
\hline Oncocytic & 0 & 0 & 1 \\
\hline Unknown & 1 & 0 & 0 \\
\hline \multicolumn{4}{|l|}{ Duct type } \\
\hline Main & 0 & 0 & 1 \\
\hline Branch & 2 & 1 & 0 \\
\hline Mixed & 0 & 2 & 2 \\
\hline Unknown & 1 & 0 & 0 \\
\hline \multicolumn{4}{|l|}{ Cyst focality } \\
\hline Single & 2 & 3 & 3 \\
\hline Multiple & 1 & 0 & 0 \\
\hline Unknown & 0 & 0 & 0 \\
\hline \multicolumn{4}{|l|}{ Mural nodule } \\
\hline Y & 0 & 3 & 3 \\
\hline $\mathrm{N}$ & 3 & 0 & 0 \\
\hline Unknown & 0 & 0 & 0 \\
\hline \multicolumn{4}{|l|}{ Cyst location } \\
\hline Head & 1 & 0 & 2 \\
\hline Body/tail & 1 & 3 & 1 \\
\hline Mixed & 1 & 0 & 0 \\
\hline CEA concentration (mg/L) & $1.13 \pm 0.53$ & $3.07 \pm 1.27$ & $7.67 \pm 7.06$ \\
\hline $\begin{array}{l}\text { CA 19-9 concentration } \\
(\mathrm{mg} / \mathrm{L})\end{array}$ & $4.00 \pm 1.48$ & $6.87 \pm 7.17$ & $117.17 \pm 142.78$ \\
\hline \multicolumn{4}{|l|}{ Cyst size } \\
\hline Cyst size $(\mathrm{cm})$ & $2.93 \pm 0.54$ & $2.50 \pm 0.41$ & $6.63 \pm 3.74$ \\
\hline$<3.0$ & 1 & 2 & 1 \\
\hline$\geq 3.0$ & 2 & 1 & 2 \\
\hline
\end{tabular}

In total, 2992 proteins were identified and 2938 proteins were quantified (Additional file 2: Table S1). A total of 28,728 peptides were identified, and 553,199 peptide spectra matches were found. In the peptide library and the nine individual samples, 2778 and 2963 proteins were identified, respectively. Comparing the peptide library with the individual samples, 2749 proteins $(91.9 \%$ of all identified proteins) were shared (Fig. 2a). In the nine individual samples, most of the identified proteins (95.7\%) were usable for quantitative analysis, as evidenced by the 2963 and 2837 proteins that were identified and quantified (Fig. 2b). Approximately $2200-2500$ proteins were quantified in each sample group. The three IPMN groups were similar with regard to the number of quantified proteins (Additional file 1: Fig. S1b). In contrast, there was substantial individual variation in the number of identified and quantified proteins within the same histological subgroups. This pattern was observed across all nine samples (Additional file 1: Fig. S1c).

On average, the number of identified and quantified proteins increased by 129 and 83, respectively, in individual samples when matched with the peptide library. In addition, the number of identified peptides rose by 752 on average in individual samples with HGD 1 displaying the greatest improvement of 2109. (Additional file 3: Table S2). As shown by the Venn diagram, approximately $77 \%$ of identified and $63 \%$ of quantified proteins overlapped in all histological groups and 337 additional proteins were identified exclusively when the search was performed with the generated peptide library. Whereas the number of proteins that overlapped in the three histological groups decreased by approximately $6 \%$ when searched without the peptide library (Additional file 1: Fig. S1d, e, Additional file 2: Table S1). This result implies that the number of proteins that were common between individual samples rose due to the contribution of the peptide library. As shown in Fig. 3, the percentage of overlapping proteins from the biological replicates in each histological grade ranged from 27 to $46 \%$. The dynamic range of the proteome spanned over seven orders of magnitude overall, but most proteins (95\%) were expressed within four orders (Fig. 4). Overall, the proteins with lower orders of magnitude were analyzed, and tumor marker proteins, such as MUC5AC, MUC1, and CEA, were quantified with high intensity in the dataset.

\section{Comparative analysis using other proteome databases}

Our bioinformatics analysis showed that secreted proteins accounted for $60.5 \%$ (1810 proteins) of the 2992 identified proteins (Additional file 1: Fig. S2a, Additional file 2: Table S1). Across SecretomeP, SignalP, and TMHMM, 1527, 682, and 381 proteins were identified, respectively (Additional file 1: Fig. S2b, Additional file 2: Table S1). Protein accession numbers were converted into gene names, and the resulting redundancy was discarded prior to comparative analysis. We compared our dataset with the Human Plasma Proteome Database to assess the likelihood that the discovered proteins are potential blood markers [54, 55]. As a result, 2299 (79.7\%) of the identified proteins were plasma proteins (Additional file 1: Fig. S2c, Additional file 2: Table S1). To determine whether the discovered proteins are expressed in the pancreas, the dataset was crossreferenced with The Human Protein Atlas (http://www.proteinatlas.org, May 31, 2017) - 2613 genes had corresponding mRNA entries 


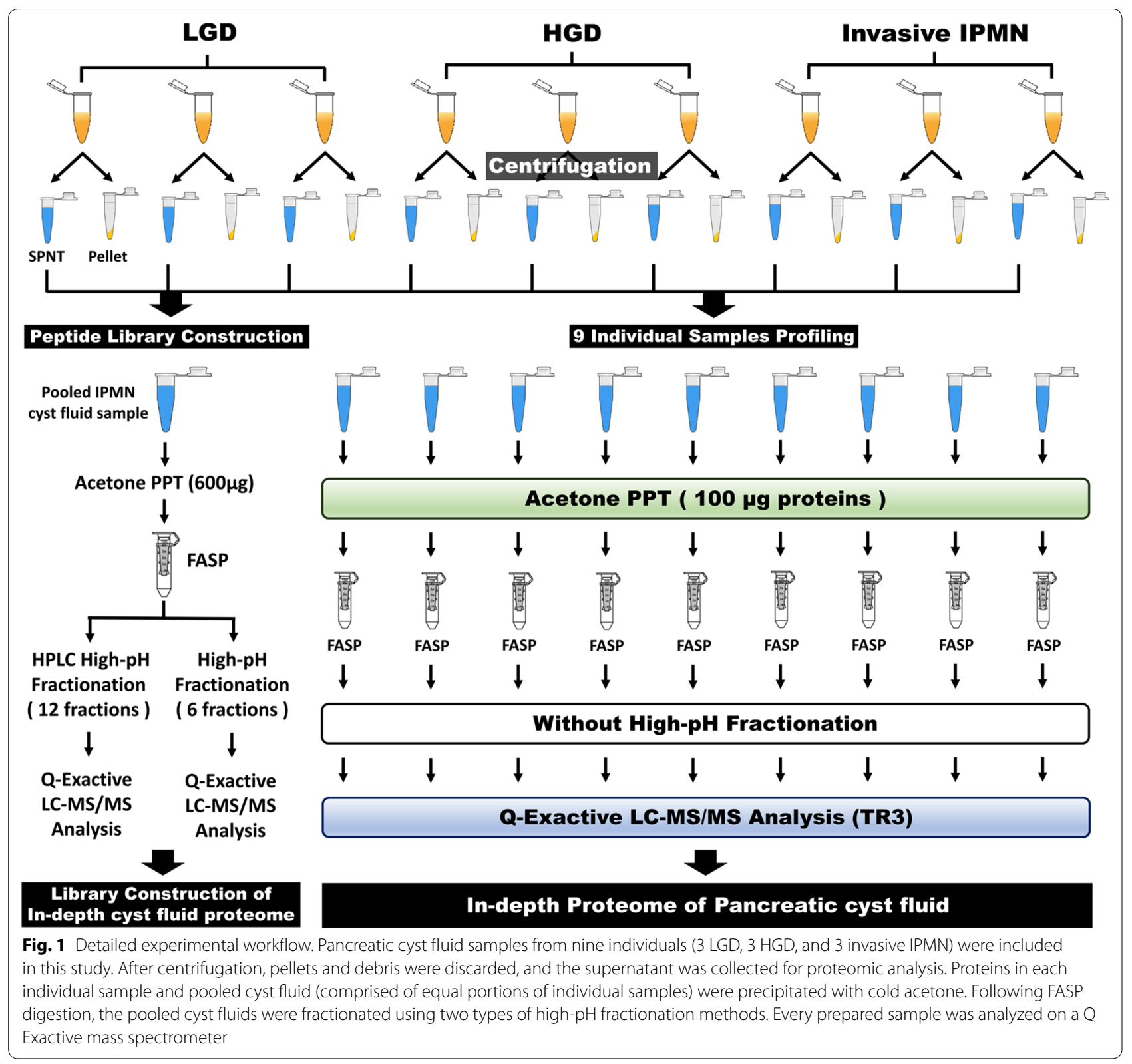

and 2021 genes had corresponding protein entries in the pancreas (Additional file 1: Fig. S2e, Additional file 2: Table S1).

\section{Variation in individual cyst samples}

Coefficient of variation (CV\%) values were calculated to evaluate the reproducibility of the technical and biological replicates. The CV\% values of log2-transformed LFQ intensity sums of technical triplicates of individual samples ranged from 0.32 to $6.45 \%$ (Additional file 4: Table S3). All CV\% values of log2-transformed LFQ intensities of each quantified protein in technical triplicates of individual samples were less than $20 \%$. Moreover, the average $\mathrm{CV} \%$ value of individual samples ranged from 1.085 to $1.524 \%$ (Additional file 1: Fig. S3a). Pearson correlation coefficients of the LFQ intensities of technical triplicates and their averages were greater than 0.9 (Fig. 5a-c, Additional file 1: Fig. S3b-d). These data suggest that the variation between technical replicates was low. In contrast, the variation between biological triplicates was generally high, based on the Pearson correlation coefficients, which ranged from 0.370 (between LGD1 and LGD2) to 0.789 (between HGD1 and HGD2) (Fig. 5d-f, Additional file 1: Fig. S3b-d).

\section{Differentially expressed proteins in IPMN dysplasia}

The 1751 proteins that had at least six valid values within a histological group were used for the statistical analysis 
a

Individual Samples

(2963)
Total

(2992)

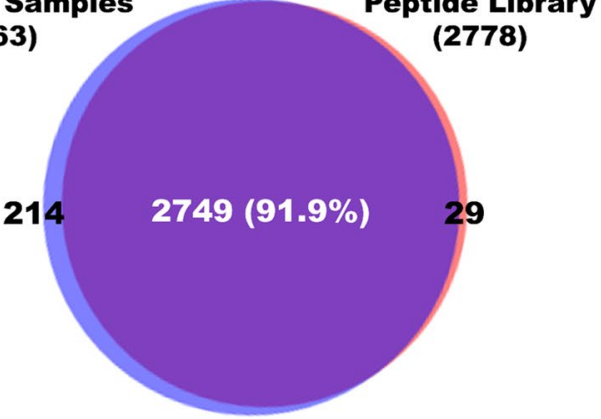

b

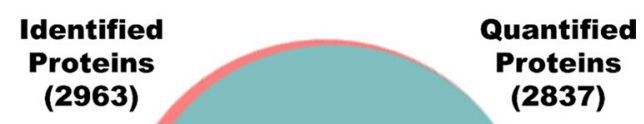

$126(4.3 \%)$

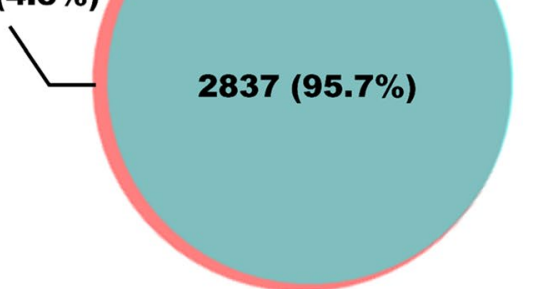

Fig. 2 Overlap of identified proteins in the individual samples and peptide library and comparison of identified and quantified proteins. a All identified proteins in the nine individual samples and peptide library; $91.9 \%$ of proteins were identified both in the individual samples and peptide library. b All identified proteins and quantified proteins in the nine individual samples; $95.7 \%$ of quantifiable proteins overlapped with the identified proteins

(Additional file 5: Table S4). By Student's $t$ test (Benjamini-Hochberg FDR=0.05), 149, 48, and 98 proteins were differentially expressed between comparisons 1 (LGD versus HGD), 2 (HGD versus invasive IPMN), and 3 (LGD versus invasive IPMN), respectively (Additional file 5: Table S4, Fig. 6), 75, 32, and 64 of which were upregulated. By unsupervised hierarchical clustering, the DEPs clustered by IPMN histology (Additional file 1: Fig. S4).

There were 243 DEPs across comparisons 1, 2, and 3. Among the 243 DEPs (Fig. 7), 142 were upregulated and 91 were downregulated in at least 1 comparison group (Additional file 6: Table S5). Enriched DEPs were used to conduct GO and KEGG pathway analyses to identify their overrepresented terms in biological process, molecular function, and cellular component. The DEPs from comparisons 1 and 3 were analyzed by ingenuity pathway analysis (IPA) bioinformatics tool to track biological processes that became activated or more pronounced in aggressive malignancy.

By GO enrichment analysis, 243 DEPs were involved primarily in vesicle-mediated transport and cell surface receptor signaling with regard to biological process. The analysis also found that $76.6 \%$ of DEPs were extracellular region proteins. The molecular functions of the DEPs were primarily associated with peptidase activity and regulation (Additional file 1: Fig. S5a-c, Additional file 7: Table S6). By KEGG pathway analysis, the 142 upregulated proteins were associated with the ribosome, oxidative phosphorylation, and endocytosis, whereas the 91 downregulated proteins were linked to leukocyte transendothelial migration, focal adhesion, and ECMreceptor interaction (Additional file 1: Fig. S5d).

The significantly changed proteins from comparison 1 and 3 were examined by IPA with regard to biological processes that are related to pancreatic cysts and aggressive malignancy. Core analysis in IPA was used to evaluate the biological functions that were most likely to be affected by changes in expression of proteins in our dataset. As a result, 149 DEPs in comparison 1 and 98 DEPs in comparison 3 were associated with such terms as cellular movement and angiogenesis in Diseases and Functions, which are indicative of malignancy; the biological terms that correlated with aggressive malignancy are highlighted in yellow (Additional file 1: Fig. S6a, b). Cell growth and vasculogenesis were upregulated among the DEPs in comparison 1. A total of 98 DEPs in comparison 3 were upregulated in most Diseases and Functions terms, except for apoptosis of tumor cell lines-particularly metastasis-related terms, such as cell spreading and angiogenesis.

Comparison analysis is usually performed to visualize trends in protein expression across several analyses. Consistent with our expectations, the Diseases and Bio functions heat map of the comparison analysis demonstrated that the DEPs that were associated with cell movement of endothelial cells and angiogenesis were more highly expressed in comparison 3 versus 1 . The term "apoptosis of tumor cell lines" was downregulated in comparison 3 but unchanged in comparison 1 (Additional file 1: Fig. S6c). A higher percentage of DEPs in comparison 3 was associated with pancreas-specific diseases, such as chronic pancreatitis and associated diseases than DEPs in comparison 1 (Additional file 1: Fig. S6d).

\section{Biomarker candidates for IPMN malignancy}

Proteins that were shared by at least two comparison groups were chosen as the initial marker candidates. Our rationale was that significantly changed proteins that are common to several comparison groups are more likely 


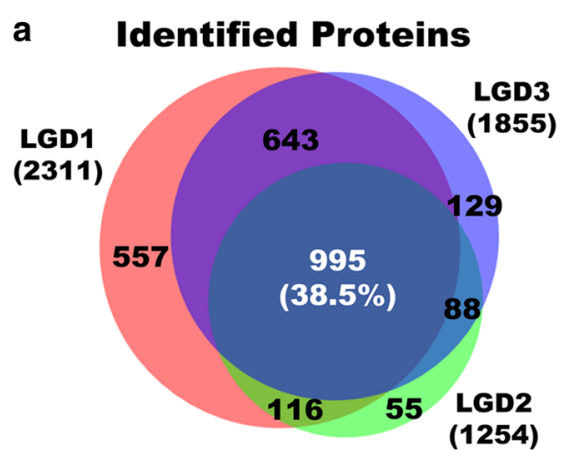

b

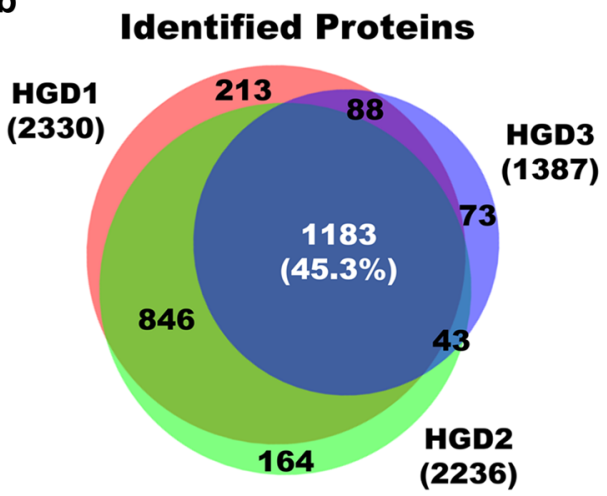

c

Identified Proteins

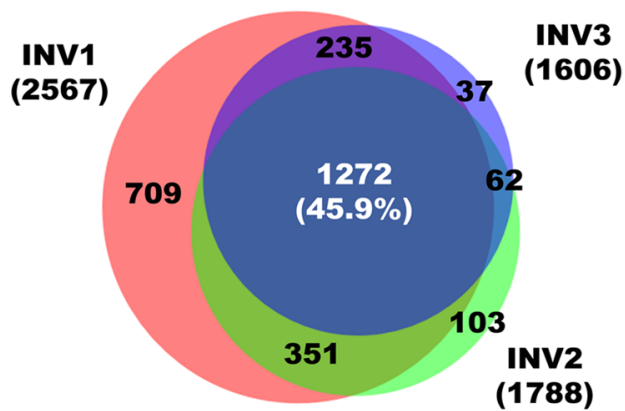

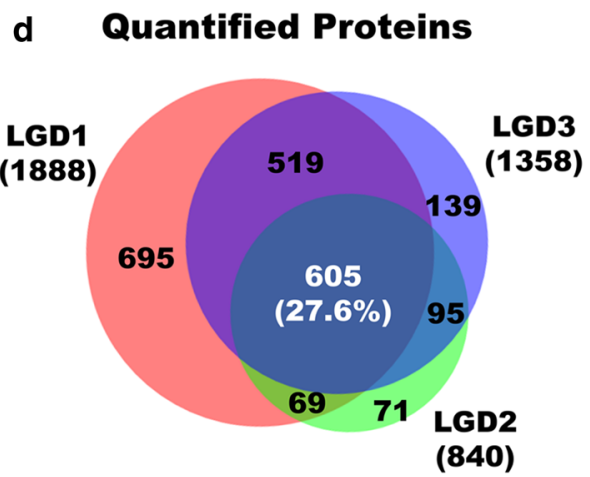

e Quantified Proteins

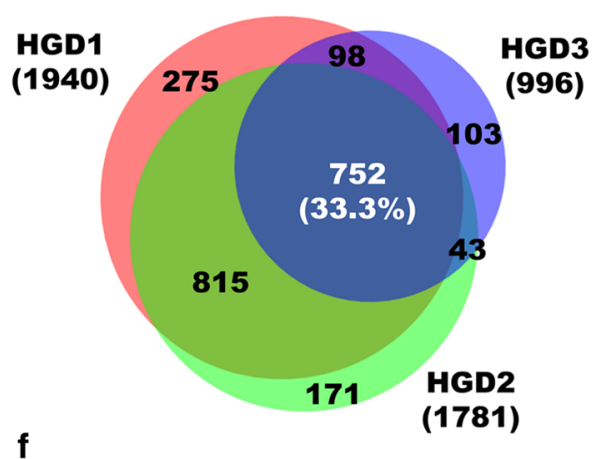

Quantified Proteins

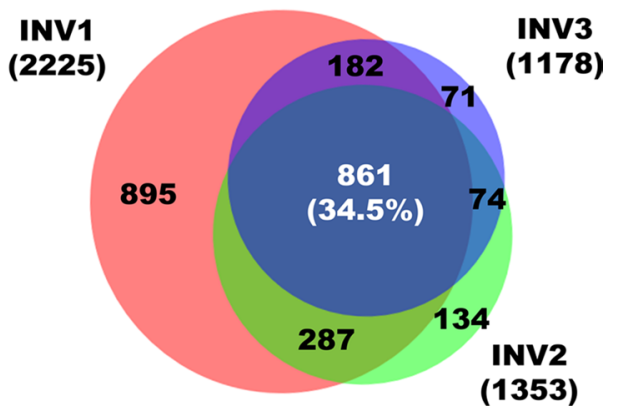

Fig. 3 Identified and quantified proteins in three individual samples for each histological grade. Identified proteins of three biological replicates in LGD (a), HGD (b), and invasive IPMN (c). Quantified proteins of three biological replicates in LGD (d), HGD (e), and invasive IPMN (f) (INV: invasive IPMN)

to be associated with the malignancy of IPMNs [60]. A total of 49 candidates expressed in at least two comparison groups were selected from 243 DEPs (Fig. 7). Then, the DEPs that had expression patterns that were consistent with the degree of IPMN malignancy were selected as the final candidates. Table 2 details the results of the statistical analysis of the 49 DEPs, including the $p$ value, fold-change, and $t$ test significance for each comparison group. Of the 49 DEPs, 38 were secreted proteins and 33 were confirmed to be expressed in the pancreas as mRNA or proteins in The Human Protein Atlas. In addition, 35 proteins were confirmed to be expressed in plasma, according to the Human Plasma Proteome Database (Table 2).

Of the 49 shared DEPs between groups, 18 had expression patterns that were consistent with the degree of malignancy. PTPN6, MUC2, TLN1, and YBX1 were expressed in lower amounts in LGD but gradually elevated in HGD and invasive IPMN. Conversely, SERPINA5, AKR1B10, and TFF1 expression decreased as IPMN histological grade progressed. Other proteins, such as HOOK1, TYMP, TEX12, FBN1, CLDN18, THY1, 


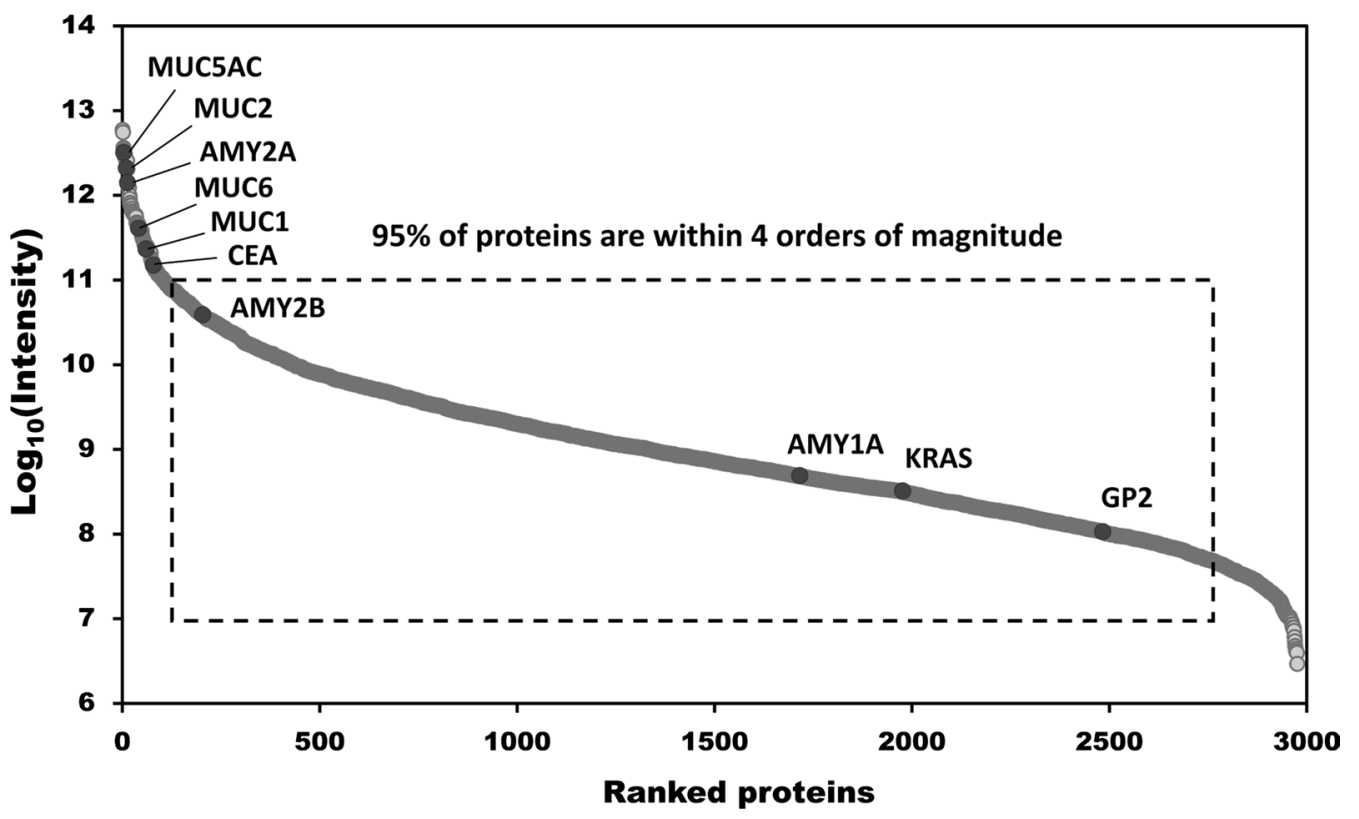

Fig. 4 Dynamic range of quantified proteins. Distribution of expression intensities of quantified proteins show a large dynamic range of abundance, but $95 \%$ of the proteins were expressed within four orders of magnitude. Several tumor marker proteins, such as MUC2, CEA, and KRAS, were quantified

MUC5AC, CST6, WFDC2, PIK3IP1, and SERPINA4, were predominantly expressed in LGD or invasive IPMN but not in other groups (Fig. 8, Additional file 1: Fig. S7). Based on these results, these 18 proteins were selected as potential biomarkers of IPMN dysplasia.

\section{Validation by western blot}

Two DEPs (HOOK1 and PTPN6) were validated by western blot using 19 pancreatic cyst fluid samples (10 LGD, 4 HGD, and 5 invasive IPMN). Patient information including demographics, cyst characteristics, and CEA and CA19-9 levels are provided in Additional file 8: Table S7. The results were then compared with the MS analysis findings (Fig. 9). Although not every western blot sample followed the trend in the MS analysis, the expression patterns of HOOK1 and PTPN6 generally correlated with the LFQ intensity values. HOOK1 was significantly upregulated in high-risk IPMN ( $p$ value $<0.01)$, and PTPN6 was detected at higher levels in high-risk IPMN $(p$ value $<0.05)$

\section{Discussion}

Most pancreatic neoplasms, which are predominantly IPMN, are discovered incidentally during routine check-ups [10]. Nevertheless, the lack of a standardized guideline adds subjectivity and undesired variability in diagnosing the malignancy of IPMN lesions. Because the concentrations of tumor biomarkers are higher in cyst fluid than in blood, pancreatic cyst fluid of IPMN patients was analyzed to discover biomarker candidates that could address these inconsistencies in diagnosing IPMN malignancy $[6,28]$. Thus, analyzing proteins that vary significantly, depending on the malignancy of IPMN, can identify biomarkers that improve the diagnostic performance of current methods and decrease the number of patients who undergo unnecessary operations $[12,20]$.

As shown in our results, we generated a pancreatic cyst fluid proteome that comprised 2992 proteins (Fig. 2a, Additional file 2: Table S1). Our proteome had three and seven times the number of proteins versus studies by Cuoghi [36] and Gbormittah [37], respectively. Further, 1291 additional proteins were identified over our previous study [38] by optimizing the standard proteomic profiling platform by constructing a peptide library of a pooled sample, methodically preparing samples, and reproducibly performing label-free quantitative analysis in triplicates (Additional file 1: Fig. S2d). Normally, DDA acquisition cannot detect low-abundance proteins in individual samples, because high-abundance proteins saturate the signal. By pooling and fractionating individual samples, these low-abundance proteins became distinct and detectable, as evidenced by a dynamic range that spanned seven orders of magnitude (Fig. 4). Consequently, the number of identified and quantified proteins that were common to all individual samples rose substantially when the mass spectra of individual samples 

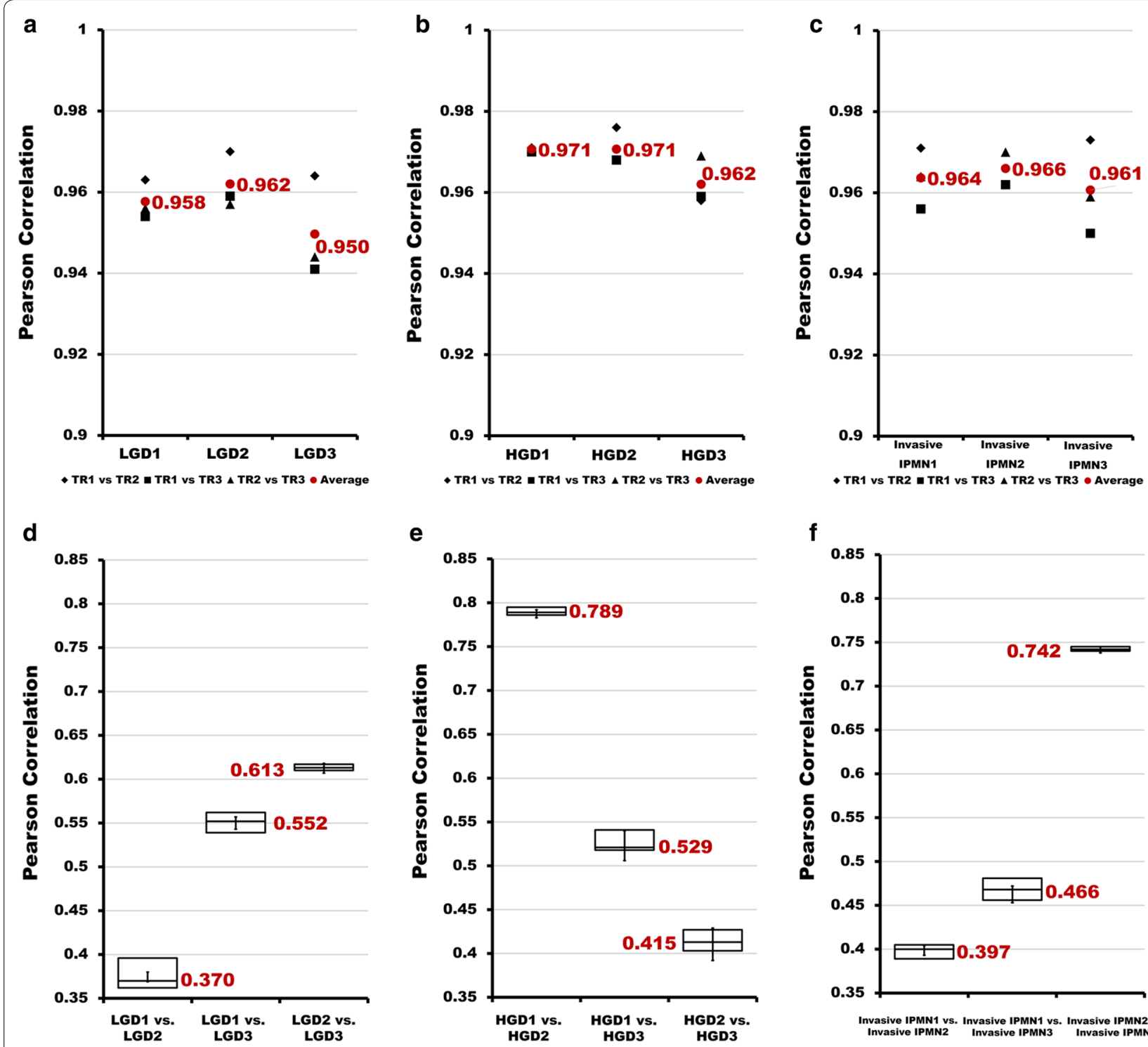

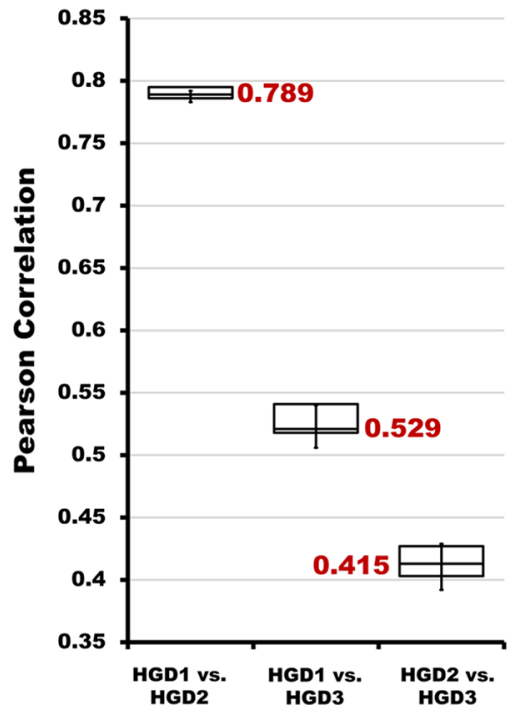

f

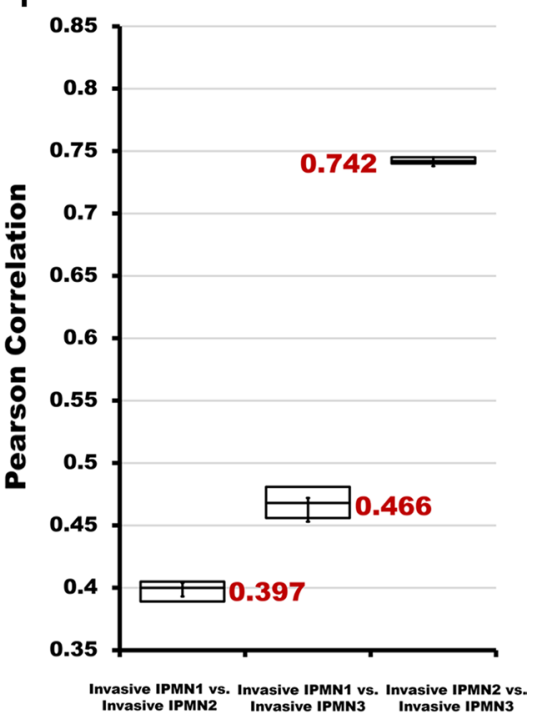

Fig. 5 Pearson correlation coefficients of technical replicates (TRs) and biological replicates in each histological group. a-c Pearson correlation coefficients of technical replicates in each histological group. Three types of marks indicate the Pearson correlation coefficients of each comparison between technical replicates ( TR1 vs. TR2, $\square$ TR1 vs. TR3, $\mathbf{A}$ TR2 vs. TR3). Red dots represent the average Pearson correlation coefficient in each of the 3 comparisons. a-c indicate LGD, HGD, and invasive IPMN, respectively. Box plot representation of Pearson correlation coefficients between each biological replicate in LGD $(\mathbf{d}), \operatorname{HGD}(\mathbf{e})$, and invasive IPMN (f)

were matched to those of the peptide library (Additional file 1: Fig. S1d, e, Additional file 3: Table S2) [61, 62]. This increase enabled us to select biomarker candidates from a larger pool of DEPs.

Most identified proteins (79.7\%) that had entries in the Plasma Proteome Database and all marker candidates in our study, except AKR1B10, CLDN18, and MUC5AC, were confirmed to be expressed in plasma (Additional file 1: Fig. S2c, Table 2). This result suggests that the discovered candidates are potential blood marker candidates. Taking into account that $70.0 \%$ of proteins were expressed in the pancreas, according to The Human Protein Atlas, it is probable that the biomarker candidates are specific to the pancreas (Additional file 1: Fig. S2e, Additional file 2: Table S1). Considering the bioinformatics analysis results of secreted proteins, we conclude that secreted proteins that originate from pancreatic epithelial cells constitute a significant portion of cyst fluid (Additional file 1: Fig. S2a, Additional file 2: Table S1). The high percentage of matches in these comparative 


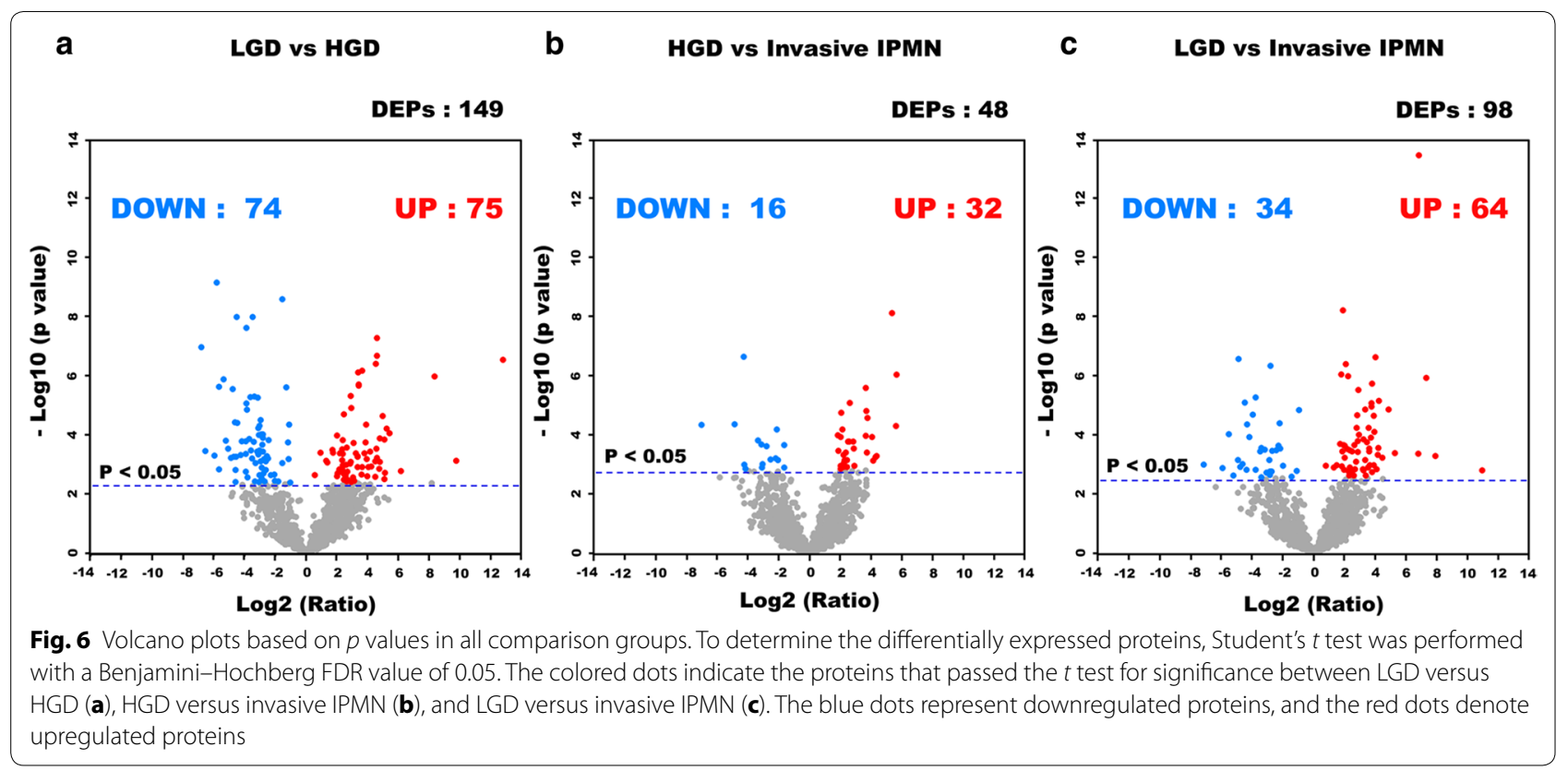

analyses confirms that virtually all of the debris was discarded and that only cyst fluid was collected during sample preparation.

The high Pearson correlation coefficients $(>0.9)$ that were obtained from the pairwise correlation analysis of LFQ intensity values indicated a strong correlation between technical triplicates and that the MS data were

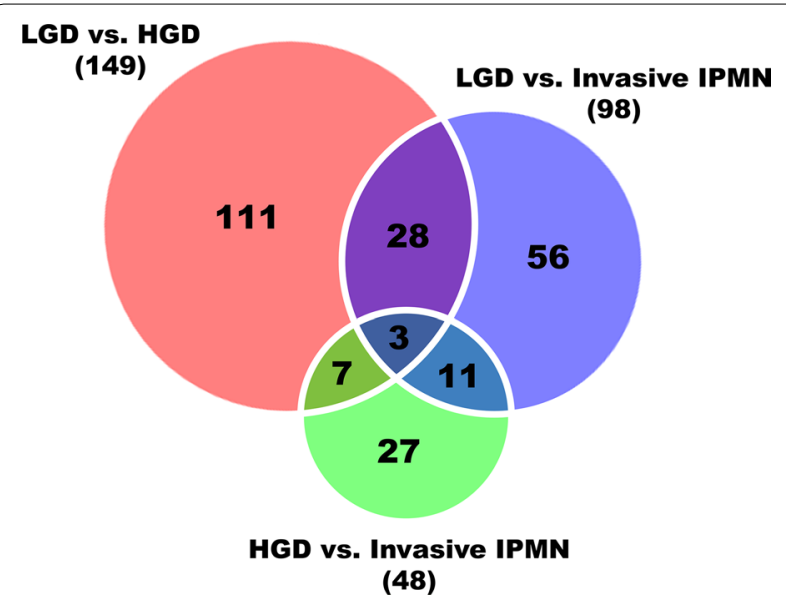

Fig. 7 Venn diagram of differentially expressed proteins in three comparison groups. By Student's $t$ test (Benjamini-Hochberg $F D R=0.05), 149,48$, and 98 proteins were differentially expressed between LGD and HGD, between HGD and invasive IPMN, and between LGD and invasive IPMN, respectively. A total 243 proteins were found to be DEPs when overlapping components of the Venn diagram were excluded; 49 proteins were shared in at least two comparison groups and are highlighted in white acquired without bias (Fig. 5a-c, Additional file 1: Fig. S3b-d). In contrast, the Pearson correlation coefficient of the biological replicates of the histology groups was low, as shown in Fig. 5d-f and Additional file 1: Fig. S3b-d, primarily due to the wide variety of cyst types, the variations in cyst size, and the presence of blood contaminants [63-65]. One possible source of variation is the contamination of cyst fluid by blood. Fortunately, the samples in this experiment were relatively clean, as evidenced by the inability to detect albumin and low (intensity rank 1475) IgG levels (Fig. 4, Additional file 2: Table S1). Despite using relatively clean cyst fluid, the variation between individual cyst fluid samples remained large (Additional file 1: Fig. S1c, Fig. 5d-f). Based on this result, we infer that using contaminated samples will result in even greater individual variation.

Selecting proteins that had at least six valid values within a histological group mitigated the likelihood of analyzing proteins that are not representative of their histology group, as evidenced from the low $p$ value of the $t$ test, the high fold-change value, and the clear division between clusters shown in the heat map (Additional file 1: Fig. S4, Additional file 5: Table S4). After eliminating DEPs that were unique to single comparison group, 18 proteins that changed expression levels in accordance with the degree of IPMN malignancy were selected as biomarker candidates (Table 2, Fig. 8, and Additional file 1: Fig. S7). Overall, our stringent criteria-requiring at least six valid values in a histological group, rigorous statistical analysis parameters, and a consistent expression pattern across histology groups-significantly 
Table 2 Detailed statistical analysis of 49 DEPs that were shared in at least two comparison groups

\begin{tabular}{|c|c|c|c|c|c|c|c|c|c|}
\hline \multirow[t]{2}{*}{ Protein name } & \multicolumn{3}{|c|}{ LGD versus $H G D$} & \multicolumn{3}{|c|}{ HGD versus invasive IPMN } & \multicolumn{3}{|c|}{ LGD versus invasive IPMN } \\
\hline & $\begin{array}{l}t \text { test signifi- } \\
\text { cance }\end{array}$ & $p$ value & $\begin{array}{l}\text { Fold- } \\
\text { change }\end{array}$ & $\begin{array}{l}t \text { test signifi- } \\
\text { cance }\end{array}$ & $p$ value & $\begin{array}{l}\text { Fold- } \\
\text { change }\end{array}$ & $\begin{array}{l}t \text { test signifi- } \\
\text { cance }\end{array}$ & $p$ value & $\begin{array}{l}\text { Fold- } \\
\text { change }\end{array}$ \\
\hline EH domain-containing protein 1 & + & 0.00594 & -15.43 & + & 0.01955 & 7.35 & & 0.54376 & -2.10 \\
\hline $\begin{array}{l}\text { Immunoglobulin lambda variable } \\
3-21\end{array}$ & + & 0.00586 & -18.35 & + & 0.00001 & 41.24 & & 0.54057 & 2.25 \\
\hline Collagen alpha-1(VI) chain & + & 0.00224 & -22.78 & + & 0.01403 & 5.61 & & 0.19350 & -4.06 \\
\hline $\begin{array}{l}\text { Vacuolar protein sorting-associ- } \\
\text { ated protein } 37 \mathrm{~B}\end{array}$ & + & 0.01350 & -6.78 & + & 0.04669 & 4.56 & & 0.76562 & -1.49 \\
\hline Ig lambda- 6 chain C region & + & 0.03265 & -4.96 & + & 0.02993 & 20.47 & & 0.31759 & 4.13 \\
\hline Ras-related protein Ral-B & + & 0.00571 & -5.53 & + & 0.00111 & 12.71 & & 0.33130 & 2.30 \\
\hline Lysozyme C & + & 0.03497 & 3.95 & + & 0.03528 & -5.79 & & 0.66323 & -1.47 \\
\hline $\begin{array}{l}\text { Immunoglobulin heavy variable } \\
\text { 1/OR15-1 }\end{array}$ & & 0.00000 & 1.00 & + & 0.02490 & 5.06 & + & 0.00046 & 7.47 \\
\hline $\begin{array}{l}\text { Immunoglobulin lambda variable } \\
5-45\end{array}$ & & 0.93977 & -1.15 & + & 0.03513 & 17.43 & + & 0.02740 & 15.11 \\
\hline $\begin{array}{l}\text { bAldo-keto reductase family } 1 \\
\text { member B10 }\end{array}$ & & 0.97902 & -1.08 & + & 0.00808 & -131.01 & + & 0.02709 & -140.91 \\
\hline Ig heavy chain V-III region TIL & & 0.22132 & -1.77 & + & 0.00288 & 6.15 & + & 0.00022 & 3.48 \\
\hline Ig heavy chain V-III region BUT & & 0.61619 & 1.58 & + & 0.01276 & 4.09 & + & 0.03193 & 6.47 \\
\hline Ig heavy chain V-III region BUR & & 0.61583 & 1.72 & + & 0.03530 & 5.43 & + & 0.03177 & 9.36 \\
\hline Ig heavy chain V-III region ZAP & & 0.81620 & 1.29 & + & 0.01443 & 6.03 & + & 0.00587 & 7.80 \\
\hline Ig alpha-2 chain C region & & 0.14392 & -2.13 & + & 0.02303 & 3.70 & + & 0.02778 & 1.74 \\
\hline aThymidine phosphorylase & & 0.89045 & -1.25 & + & 0.00774 & 48.91 & + & 0.01333 & 39.00 \\
\hline $\begin{array}{l}\text { aTestis-expressed sequence } 12 \\
\text { protein }\end{array}$ & & 0.75598 & -1.40 & + & 0.01204 & 16.69 & + & 0.00379 & 11.94 \\
\hline aProtein Hook homolog 1 & & 0.33603 & 2.29 & + & 0.00053 & 50.05 & + & 0.00000 & 114.50 \\
\hline Collagen alpha-1(XV) chain & + & 0.00001 & -11.37 & & 0.54289 & 1.75 & + & 0.01252 & -6.49 \\
\hline Prosaposin & + & 0.01353 & -2.27 & & 0.69798 & 1.16 & + & 0.00131 & -1.95 \\
\hline $\begin{array}{l}\text { bPhosphoinositide-3-kinase- } \\
\text { interacting protein } 1\end{array}$ & + & 0.00707 & -7.41 & & 0.00000 & 1.00 & + & 0.01999 & -7.35 \\
\hline ' Thy-1 membrane glycoprotein & + & 0.00966 & -8.39 & & 0.00000 & 1.00 & + & 0.01176 & -10.48 \\
\hline $\begin{array}{l}\text { Latent-transforming growth fac- } \\
\text { tor beta-binding protein } 2\end{array}$ & + & 0.01295 & -30.47 & & 0.83621 & 1.13 & + & 0.02886 & -26.88 \\
\hline Protein disulfide-isomerase A3 & + & 0.00534 & 27.04 & & 0.64689 & -1.78 & + & 0.00176 & 15.23 \\
\hline Agrin & + & 0.01010 & -95.04 & & 0.64723 & 1.58 & + & 0.03007 & -59.97 \\
\hline Alpha-1-antichymotrypsin & + & 0.00041 & -8.93 & & 0.52129 & 1.65 & + & 0.01226 & -5.40 \\
\hline Collagen alpha-1(IV) chain & + & 0.00000 & -23.08 & & 0.36550 & 2.54 & + & 0.01235 & -9.09 \\
\hline 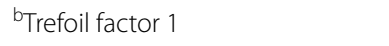 & + & 0.03148 & -4.27 & & 0.32370 & -4.75 & + & 0.03214 & -20.28 \\
\hline bPlasma serine protease inhibitor & + & 0.00000 & -3.00 & & 0.07044 & -2.33 & + & 0.00013 & -7.00 \\
\hline $\begin{array}{l}\text { Guanine nucleotide-binding } \\
\text { protein } G(k) \text { subunit alpha }\end{array}$ & + & 0.00446 & -7.09 & & 0.57151 & 1.44 & + & 0.01032 & -4.92 \\
\hline $\begin{array}{l}\text { Guanine nucleotide-binding } \\
\text { protein } G(k) \text { subunit alpha }\end{array}$ & + & 0.00042 & -12.58 & & 0.94988 & -1.07 & + & 0.00077 & -13.45 \\
\hline Collagen alpha-3(VI) chain & + & 0.00016 & -41.81 & & 0.61089 & 2.11 & + & 0.00316 & -19.85 \\
\hline $\begin{array}{l}\text { aTyrosine-protein phosphatase } \\
\text { non-receptor type } 6\end{array}$ & + & 0.02363 & 4.39 & & 0.50095 & 1.58 & + & 0.00391 & 6.95 \\
\hline${ }^{b}$ Kallistatin & + & 0.01495 & -6.30 & & 0.68656 & 1.42 & + & 0.01178 & -4.45 \\
\hline${ }^{b}$ Fibrillin-1 & + & 0.00000 & -57.02 & & 0.43700 & 1.93 & + & 0.00012 & -29.49 \\
\hline${ }^{\mathrm{b}}$ Claudin-18 & + & 0.00001 & -14.94 & & 0.67515 & -1.49 & + & 0.00101 & -22.20 \\
\hline Coronin-7 & + & 0.00858 & 6.09 & & 0.85877 & -1.18 & + & 0.01207 & 5.15 \\
\hline 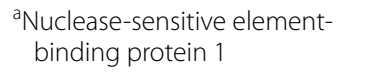 & + & 0.04238 & 6.17 & & 0.62145 & 1.67 & + & 0.00138 & 10.30 \\
\hline
\end{tabular}


Table 2 continued

\begin{tabular}{|c|c|c|c|c|c|c|c|c|c|c|c|c|c|c|}
\hline \multirow[t]{2}{*}{ Protein name } & \multicolumn{6}{|c|}{ LGD versus HGD } & \multicolumn{4}{|c|}{ HGD versus invasive IPMN } & \multicolumn{4}{|c|}{ LGD versus invasive IPMN } \\
\hline & \multicolumn{2}{|c|}{$\begin{array}{l}t \text { test signifi- } \\
\text { cance }\end{array}$} & \multicolumn{2}{|c|}{$p$ value } & \multicolumn{2}{|c|}{$\begin{array}{l}\text { Fold- } \\
\text { change }\end{array}$} & \multicolumn{2}{|c|}{$\begin{array}{l}t \text { test signifi- } \\
\text { cance }\end{array}$} & $p$ value & $\begin{array}{l}\text { Fold- } \\
\text { change }\end{array}$ & \multicolumn{2}{|c|}{$\begin{array}{l}t \text { test signifi- } \\
\text { cance }\end{array}$} & $p$ value & $\begin{array}{l}\text { Fold- } \\
\text { change }\end{array}$ \\
\hline Histone H3.1 & \multicolumn{2}{|l|}{+} & \multicolumn{2}{|c|}{0.00023} & \multicolumn{2}{|c|}{10.62} & & & 0.25248 & -2.30 & \multicolumn{2}{|l|}{+} & 0.01205 & 4.62 \\
\hline${ }^{b}$ Mucin-5AC & \multicolumn{2}{|l|}{+} & \multicolumn{2}{|c|}{0.02741} & \multicolumn{2}{|c|}{-15.38} & & & 0.69722 & -1.94 & \multicolumn{2}{|l|}{+} & 0.02010 & -29.87 \\
\hline aMucin-2 & \multicolumn{2}{|l|}{+} & \multicolumn{2}{|c|}{0.00006} & \multicolumn{2}{|c|}{7068.07} & & & 0.76813 & -3.54 & + & & 0.03333 & 1996.84 \\
\hline $\begin{array}{l}\text { bWAP four-disulfide core domain } \\
\text { protein } 2\end{array}$ & + & & & 0554 & -13.2 & & & & 0.83040 & -1.38 & + & & 0.00690 & -18.23 \\
\hline${ }^{b}$ Cystatin-M & + & & & 1152 & -19.4 & & & & 0.00000 & 1.00 & + & & 0.03235 & -13.72 \\
\hline $\begin{array}{l}\text { BPI fold-containing family B } \\
\text { member } 1\end{array}$ & + & & & 0026 & -27.5 & & & & 0.49944 & 1.78 & + & & 0.00180 & -15.53 \\
\hline Intelectin-1 & + & & & 1505 & 844.3 & & & & 0.76240 & -3.48 & + & & 0.01605 & 242.93 \\
\hline aTalin-1 & + & & & 3653 & 8. & 08 & & & 0.60098 & 1.46 & + & & 0.02980 & 11.78 \\
\hline $\begin{array}{l}\text { Basement membrane-specific } \\
\text { heparan sulfate proteoglycan } \\
\text { core protein }\end{array}$ & + & & & 0003 & -114.3 & & + & & 0.00582 & 13.69 & + & & 0.03552 & -8.35 \\
\hline Histone H3 & + & & & 0007 & 22.8 & & + & & 0.01650 & -3.15 & + & & 0.00843 & 7.26 \\
\hline $\begin{array}{l}\text { Cadherin-related family member } \\
2\end{array}$ & + & & & 0024 & -52.1 & & + & & 0.02477 & 13.15 & + & & 0.02747 & -3.96 \\
\hline Protein name & & Signa & & Secret & tomeP & & HMM & The Hur & man Prote & ein Atlas & & Hum & Ian plasm & roteome \\
\hline & & Passe & & Passec & & & sed & RNA exp & pression & Protein ex & ression & Inclu & ded & \\
\hline EH domain-containing protein 1 & & - & & - & & - & & Y & & - & & Y & & \\
\hline Immunoglobulin lambda variable 3 & $3-21$ & Y & & Y & & - & & - & & - & & - & & \\
\hline Collagen alpha-1(VI) chain & & Y & & - & & - & & Y & & - & & Y & & \\
\hline $\begin{array}{l}\text { Vacuolar protein sorting-associated } \\
37 \mathrm{~B}\end{array}$ & protein & - & & - & & - & & Y & & Y & & Y & & \\
\hline Ig lambda- 6 chain $C$ region & & - & & Y & & - & & - & & - & & - & & \\
\hline Ras-related protein Ral-B & & - & & - & & - & & Y & & Y & & - & & \\
\hline Lysozyme C & & Y & & Y & & - & & Y & & Y & & Y & & \\
\hline Immunoglobulin heavy variable $1 / 0$ & OR15-1 & Y & & Y & & - & & - & & - & & - & & \\
\hline Immunoglobulin lambda variable 5 & $5-45$ & Y & & Y & & - & & - & & - & & - & & \\
\hline${ }^{b}$ Aldo-keto reductase family 1 mem & nber B10 & - & & - & & - & & - & & - & & - & & \\
\hline Ig heavy chain V-III region TIL & & - & & Y & & - & & - & & - & & - & & \\
\hline Ig heavy chain V-III region BUT & & - & & Y & & - & & - & & - & & - & & \\
\hline Ig heavy chain V-III region BUR & & - & & Y & & - & & - & & - & & - & & \\
\hline Ig heavy chain V-III region ZAP & & - & & - & & - & & - & & - & & - & & \\
\hline Ig alpha-2 chain $C$ region & & - & & Y & & - & & - & & - & & Y & & \\
\hline aThymidine phosphorylase & & - & & Y & & - & & Y & & - & & Y & & \\
\hline 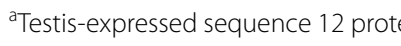 & & - & & Y & & - & & - & & - & & Y & & \\
\hline aProtein Hook homolog 1 & & - & & - & & - & & Y & & - & & Y & & \\
\hline Collagen alpha-1 $(\mathrm{XV})$ chain & & - & & - & & - & & Y & & - & & Y & & \\
\hline Prosaposin & & Y & & Y & & - & & Y & & Y & & Y & & \\
\hline $\begin{array}{l}\text { bPhosphoinositide-3-kinase-interac } \\
\text { protein } 1\end{array}$ & cting & Y & & - & & - & & Y & & - & & Y & & \\
\hline bThy-1 membrane glycoprotein & & Y & & - & & - & & Y & & - & & Y & & \\
\hline $\begin{array}{l}\text { Latent-transforming growth factor } \\
\text { binding protein } 2\end{array}$ & beta- & Y & & - & & - & & Y & & - & & Y & & \\
\hline Protein disulfide-isomerase A3 & & - & & - & & - & & Y & & Y & & Y & & \\
\hline Agrin & & Y & & - & & - & & Y & & - & & Y & & \\
\hline Alpha-1-antichymotrypsin & & Y & & Y & & - & & Y & & Y & & Y & & \\
\hline Collagen alpha-1(IV) chain & & Y & & - & & - & & Y & & - & & Y & & \\
\hline${ }^{\mathrm{b}}$ Trefoil factor 1 & & Y & & Y & & - & & Y & & - & & Y & & \\
\hline
\end{tabular}


Table 2 continued

\begin{tabular}{|c|c|c|c|c|c|c|}
\hline \multirow[t]{2}{*}{ Protein name } & \multirow{2}{*}{$\begin{array}{l}\text { SignalP } \\
\text { Passed }\end{array}$} & \multirow{2}{*}{$\begin{array}{l}\text { SecretomeP } \\
\text { Passed }\end{array}$} & \multirow{2}{*}{$\begin{array}{l}\text { TMHMM } \\
\text { Passed }\end{array}$} & \multicolumn{2}{|c|}{ The Human Protein Atlas } & \multirow{2}{*}{$\begin{array}{l}\text { Human plasma proteome } \\
\text { Included }\end{array}$} \\
\hline & & & & RNA expression & Protein expression & \\
\hline${ }^{b}$ Plasma serine protease inhibitor & Y & Y & - & Y & - & Y \\
\hline $\begin{array}{l}\text { Guanine nucleotide-binding protein } \mathrm{G}(\mathrm{k}) \\
\text { subunit alpha }\end{array}$ & - & Y & - & Y & Y & Y \\
\hline $\begin{array}{l}\text { Guanine nucleotide-binding protein } G(k) \\
\text { subunit alpha }\end{array}$ & Y & - & - & Y & Y & Y \\
\hline Collagen alpha-3(VI) chain & Y & - & - & Y & - & Y \\
\hline $\begin{array}{l}\text { aTyrosine-protein phosphatase non-recep- } \\
\text { tor type } 6\end{array}$ & - & - & - & Y & - & Y \\
\hline${ }^{\text {bKallistatin }}$ & Y & Y & - & Y & Y & Y \\
\hline${ }^{b}$ Fibrillin-1 & Y & - & - & Y & - & Y \\
\hline${ }^{b}$ Claudin-18 & - & - & Y & Y & - & - \\
\hline Coronin-7 & - & - & - & Y & Y & Y \\
\hline $\begin{array}{l}{ }^{a} \text { Nuclease-sensitive element-binding } \\
\text { protein } 1\end{array}$ & - & Y & - & Y & Y & Y \\
\hline Histone H3.1 & - & Y & - & - & Y & - \\
\hline${ }^{b}$ Mucin-5AC & Y & - & - & - & - & - \\
\hline aMucin-2 & Y & - & - & - & - & Y \\
\hline bWAP four-disulfide core domain protein 2 & Y & Y & Y & Y & - & Y \\
\hline${ }^{\mathrm{b}}$ Cystatin-M & Y & Y & - & - & - & Y \\
\hline BPI fold-containing family B member 1 & Y & Y & Y & - & - & Y \\
\hline Intelectin-1 & Y & Y & - & Y & - & Y \\
\hline aTalin-1 & - & - & - & Y & Y & Y \\
\hline $\begin{array}{l}\text { Basement membrane-specific heparan } \\
\text { sulfate proteoglycan core protein }\end{array}$ & Y & - & - & Y & Y & Y \\
\hline Histone $\mathrm{H} 3$ & - & Y & - & - & Y & - \\
\hline Cadherin-related family member 2 & Y & Y & Y & - & - & Y \\
\hline
\end{tabular}

a Dominantly expressed in invasive IPMN

b Dominantly expressed in LGD

increased the probability of finding more credible biomarker candidates.

All 18 biomarker candidates were associated with pancreatic disease and malignancy (Additional file 9: Table S8). With the exception of HOOK1, TEX12, TLN1, and PIK3IP1, all candidates are expressed in pancreatic tissue [66-94]. Twelve candidates were associated with pancreatic diseases, such as IPMN, pancreatic ductal adeno carcinoma (PDAC), and pancreatitis [66-79, 81-85, 87, 88, 92-97]. According to Tanaka, CLDN18 is an earlystage marker of PDAC and is elevated in high-grade versus low-grade lesions, consistent with our data [5]. Two types of mucin proteins were selected as biomarker candidates and have been examined in studies on IPMN and pancreatic cancer. Our protein expression patterns were consistent with those of prior studies. One of the two mucin biomarkers, MUC5AC, is expressed at high levels during the early stages of pancreatic ductal dysplasia but is low in high-grade tumors [70, 72]. MUC2 is expressed in IPMNs but not normal pancreatic tissue or PDAC [70].
PTPN6, YBX1, TYMP, CLDN18, WFDC2, SERPINA4, TFF1, MUC2, MUC5AC, CST6, THY1, and AKR1B10 overexpressed in PDAC and pancreatitis. PTPN6 has not been reported in human pancreatic samples but has been observed in PANC-1 cell lines and a rat model of pancreatitis $[95,96]$. The upregulated proteins, YBX1 and TYMP, are expressed at higher levels in PDAC versus normal tissue, a pattern that is consistent with our proteomic data [87, 88]. In addition, these candidates are overexpressed in other types of cancer, such as breast and bladder cancer [98-101]. The remaining six candidates, except SERPINA4 and MUC2, are overexpressed in PDAC [66-68, 71, 79, 81, 93]. These proteins are involved in tumor progression and differentiation. Accordingly, they are regarded as marker candidates of various cancer types. WFDC2 is a potential early diagnostic marker of gynecological cancers, such as ovarian and endometrial cancer [102]. Moreover, serum levels of WFDC2 are indicative of ovarian cancer [103]. TFF1, THY1, and AKR1B10 are associated with various cancers and have 

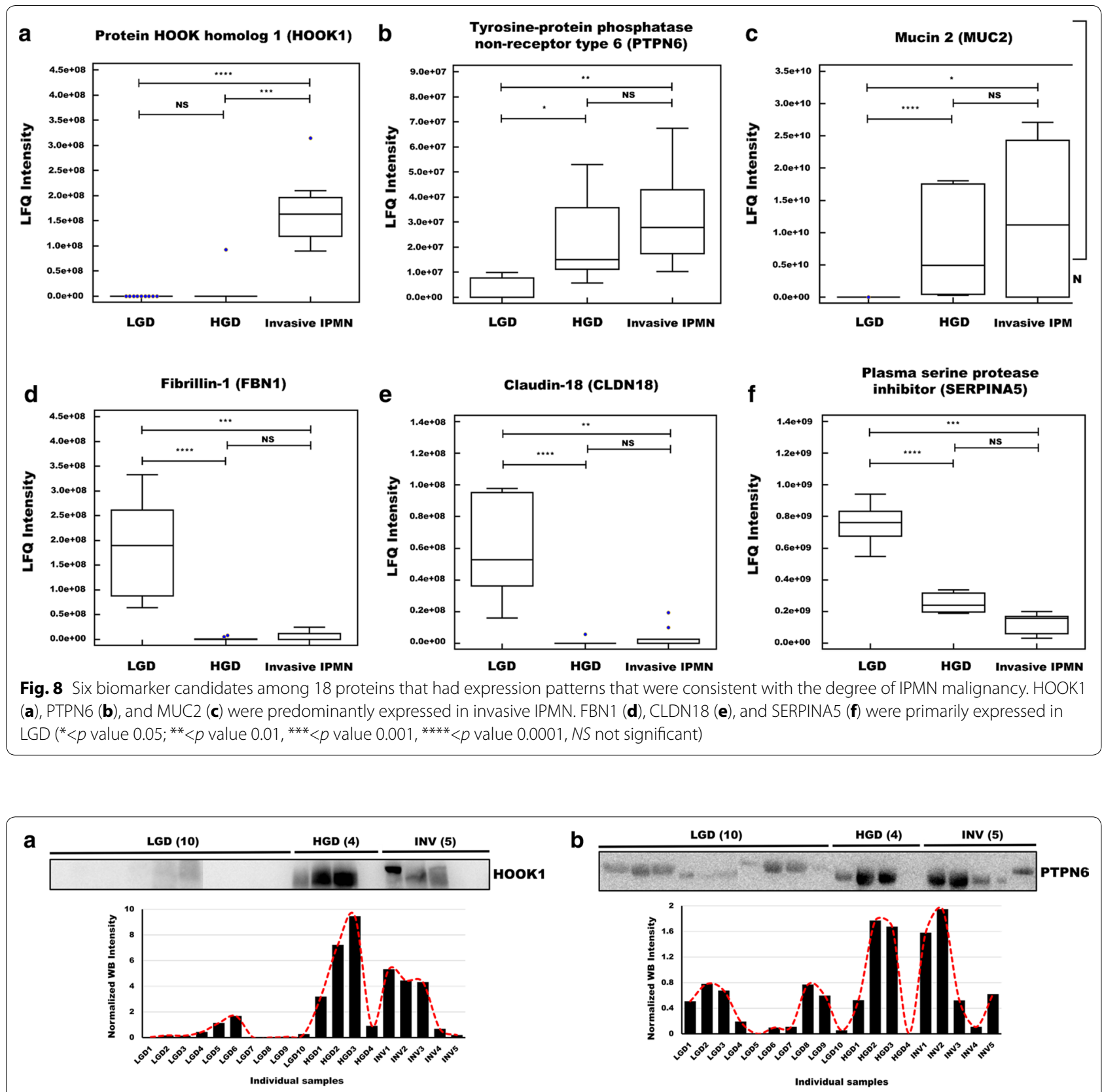

b $\frac{\text { LGD (10) }}{\text { HGD (4) }} \frac{\text { INV (5) }}{\text { PE }}$
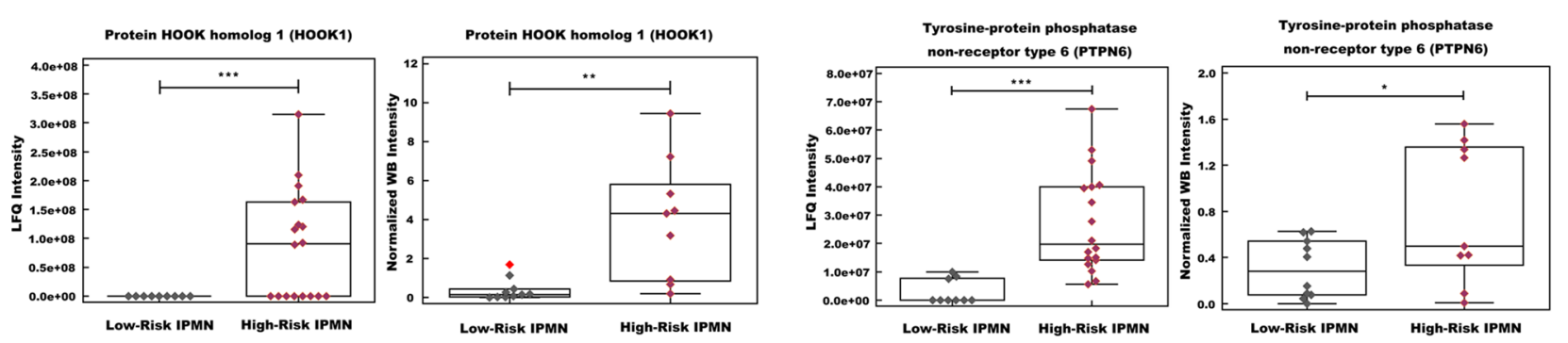

Fig. 9 Validation of HOOK1 and PTPN6 as potential biomarker targets by western blot. A total of 19 pancreatic cyst fluid samples were analyzed by western blot to validate the relative abundance of HOOK1 and PTPN6. The immunoblotting results were consistent with our MS results. a HOOK1 was overexpressed in high-risk IPMN in the proteomic ( $p$ value $<0.001)$ and western blot analyses $(p$ value $<0.01)$. b PTPN6 was overexpressed in high-risk IPMN in the proteomic ( $p$ value $<0.001)$ and western blot analyses ( $p$ value $<0.05)\left({ }^{*}<p\right.$ value $0.05,{ }^{* *}<p$ value $0.01,{ }^{* * *}<p$ value 0.001 , **** $<p$ value 0.0001 , NS not significant, INV invasive IPMN) 
been implicated as biomarker candidates [104-108]. Although it is unknown whether SERPINA4 mediates the progression of pancreatic cancer, it is an early marker of severity in acute pancreatitis [97]. These studies have demonstrated that our final list comprises bona fide candidate markers for IPMN. Our report has significance as the first study to discover the following marker candidates of IPMN: HOOK1, TEX12, TLN1, SERPINA5, FBN1, and PIK3IP1. With the exception of TEX12, these proteins are associated with other cancers, such as hepatocellular carcinoma, breast cancer, and prostate cancer [109-121]. Considering the literature regarding the 18 candidates, it is likely that they are related to IPMN malignancy, except for TEX12.

In order to confirm the validity of the aforementioned marker candidates, we compared our MS analysis results with western blot results. Western blot with cyst fluids is difficult due to the lack of housekeeping proteins, such as alpha-tubulin and beta-actin. To address this issue, we used $0.1 \%$ Ponceau S solution as a loading control (Additional file 1: Fig. S8, Additional file 10: Table S9) [122, 123]. The $\mathrm{CV} \%$ of the intensities of individual samples was $14.19 \%$, indicating that approximately equal amounts had been loaded onto the SDS-PAGE gels. Three DEPs were selected for further validation: two upregulated (HOOK1 and PTPN6) and one downregulated protein (SERPINA5). The selection criteria for validation were a low $p$ value, high LFQ intensities, and a lack of an association with IPMN in the literature (which suggests novelty).

HOOK1 was highly expressed in HGD and invasive IPMN compared with LGD $(p<0.01)$. Although the difference in PTPN6 was not statistically significant between the three comparison groups, its overall expression pattern underwent similar changes as in the MS results (Additional file 1: Fig. S9a, b). The expression pattern of SERPINA5 was not consistent with the MS analysis and was higher in high-risk IPMN (Additional file 1: Fig. S9c). This inconsistency might have resulted from the inherent property of western blots, which depends on the affinity between an antibody and a single antigenic epitope [124-132]. Thus, if the antibody has weak affinity for the epitope, the western blot results would not be an accurate measure of protein abundance. In this regard, although western blot has been the standard assay in proteomics, targeted proteomic analysis might be a better alternative for verifying our quantitative MS data.

\section{Conclusions}

We have identified 2992 proteins in IPMN cyst fluid samples using mass spectrometry techniques. Our investigation demonstrates that the use of a peptide library is beneficial, because the increased number of identified proteins provides a wider selection to choose from as biomarkers. This is evident from our dataset, which contains the largest number of proteins for pancreatic cyst fluid. Our in-depth data on the pancreatic cyst fluid proteome will be a valuable resource for pancreatic disease research.

Our bioinformatics analysis concluded that upregulated DEPs were associated with pancreatic cell proliferation and aggressive malignancy. Through statistical analysis, we designated 18 biomarker candidates that changed expression levels, depending on the histological grade of IPMN. Among them, two upregulated DEPs were consistent with our western blot analysis. The literature has also concluded that these proteins are involved primarily in pancreatic diseases and malignancy, rendering them promising biomarker candidates of IPMN malignancy. In future studies, we plan to collect a sufficient amount of cyst fluid samples from more patients to test the performance of these biomarkers by immunoassay and multiple reaction monitoring (MRM).

\section{Additional files}

Additional file 1. Supplementary Figures S1-S9.

Additional file 2. Table S1. List of identified proteins. MS information on identified and quantitated proteins is listed consecutively. SignalP and SecretomeP were used to identify the secreted proteins, whereas TMHMM was used to identify transmembrane proteins. The Human Plasma

Proteome Database confirmed the association between the proteins that were identified in human plasma and the identified proteins of this study. Identified proteins in our dataset were crossreferenced with pancreatic expression in the Human Protein Atlas. LFQ intensities of individual samples were used for further statistical analysis. The additional proteins searched exclusively in the presence of peptide library were highlighted as the additional column in this table.

Additional file 3. Table S2. The number of identified and quantified proteins in individual samples searched with and without the peptide library. The number of identified and quantified proteins increased by 129 and 83 , respectively, on average per individual samples when searched with and without the peptide library. In the same manner, the number of identified peptides rose by 752 on average in individual samples with HGD1 presenting the greatest improvement of 2109.

Additional file 4. Table S3. Coefficient of variation (CV\%) values of the sums of logarithm base two-transformed LFQ intensities of technical triplicates. The CV\% values were calculated in each pancreatic cyst fluid sample (Technical replicate 1:TR1, Technical replicate 2:TR2, Technical replicate $3: \operatorname{TR3}$ )

Additional file 5. Table S4. Results of the statistical analysis. Statistical significance, $p$ values, and fold-changes for 1751 proteins by Student's $t$ test (Benjamini-Hochberg FDR $=0.05$ ) in three comparison sets (comparison set 1, LGD versus HGD; comparison set 2, HGD versus invasive IPMN; comparison set 3, LGD versus Invasive IPMN).

Additional file 6. Table S5. List of exclusively upregulated, exclusively downregulated, and up- or downregulated proteins in all comparison groups. Of the 243 DEPs, 142 were upregulated and 91 were downregulated in at least one comparison group; 10 proteins were up- or downregulated by Student's $t$ test (INV: invasive IPMN).

Additional file 7. Table S6. Gene ontology analysis results. GO annotation was performed using the DAVID bioinformatics tool. The $p$ value (modified 
Fisher exact $p$ value) cutoff for the $\mathrm{GO}$ annotation was set to $<0.05$. Genes that were involved in each $G O$ term are provided as official gene symbols. 'GO FAT' filters broad GO terms, based on the measured specificity of each term.

Additional file 8. Table S7. Demographic and clinical characteristics of the study population for validation. A total of 19 pancreatic cyst fluid samples were used to confirm the credibility of marker candidates.

Additional file 9. Table S8. Previous studies that reference the 18 potential biomarker candidates. The associated categories include pancreatic diseases (IPMN, pancreatic cancer, pancreatitis), expression in the pancreas, malignancy, and association with other cancers.

Additional file 10. Table S9. Ponceau S intensity. Densitometric analysis of Ponceau $S$ intensities, used as an alternative loading control to actin in western blots (LGD: Low-grade dysplasia, HGD: High-grade dysplasia, INV: invasive IPMN).

\section{Abbreviations}

LGD: low-grade dysplasia; IGD: intermediate-grade dysplasia; HGD: high-grade dysplasia; IPMN: intraductal papillary mucinous neoplasm; MCN: mucinous cystic neoplasm; DEP: differentially expressed protein; MRI: magnetic resonance imaging; CT: computed tomography; CEA: carcinoembryonic antigen; CA19-9: carbohydrate antigen 19-9; KRAS: GTPase Kras; GNAS: guanine nucleotide-binding protein alpha subunit; BCA: bicinchoninic acid assay; SDS: sodium dodecyl sulfate; $A B C$ : ammonium bicarbonate; TFA: trifluoroacetic acid; HPLC: high-performance liquid chromatography; RP: reverse phase; ACN: acetonitrile; HCD: higher-energy collisional dissociation; NCE: normalized collision energy; FDR: false discovery rate; GO: gene ontology; BP: biological process; CC: cellular component; MF: molecular function; TMHMM: transmembrane helices; PVDF: polyvinylidene; BSA: bovine serum albumin; $\mathrm{ECL}$ : enhanced chemiluminescence; CV: coefficient of variation; LFQ: label-free quantification; DDA: data-dependent acquisition; PDAC: pancreatic ductal adenocarcinoma; HOOK1: protein HOOK homolog 1; PTPN6: tyrosine-protein phosphatase non-receptor type 6; MUC2: mucin 2; FBN1: fibrillin-1; CLDN18: caludin-18; SERPINA5: plasma serine protease inhibitor; TYMP: tyrosine phosphorylase; TLN1: talin-1; YBX1: nuclease-sensitive element-binding protein 1; TEX12: testis-expressed sequence 12 protein; AKR1B10: aldo-keto reductase family 1 member B10; THY1: Thy-1 membrane glycoprotein; MUC5AC: mucin5AC; CST6: cystatin-M; WFDC2: WAP four-disulfide domain protein 2; PIK3IP1: phosphoinositide-3-kinase-interacting protein 1; SERPINA4: kallistatin;TFF1: trefoil factor 1.

\section{Authors' contributions}

$J-Y J$ and YK contributed to the study concept and design; MD and DH contributed to the acquisition of data; $\mathrm{MD}$ contributed to the statistical analysis; $H K$ and $Y K$ contributed to the obtainment of funding; HK, WK, YH, and J-YJ contributed to administrative, technical, or material support; and MD, DH, JW, and YK contributed to the drafting of this manuscript. All authors read and approved the final manuscript.

\section{Author details}

1 Department of Biomedical Sciences, Seoul National University College of Medicine, 28 Yeongeon-dong, Seoul 110-799, Korea. ${ }^{2}$ Department of Biomedical Engineering, Seoul National University College of Medicine, 28 Yeongeon-dong, Seoul 110-799, Korea. ${ }^{3}$ Department of Surgery, Seoul National University College of Medicine, 28 Yeongeon-dong, Seoul 110-799, Korea. ${ }^{4}$ Proteomics Core Facility, Biomedical Research Institute, Seoul National University Hospital, 101 Daehak-ro, Seoul, Korea.

\section{Acknowledgements}

This work was supported by the Collaborative Genome Program for Fostering New Post-Genome Industry (NRF-2017M3C9A5031597), a National Research Foundation Grant (No. 2011-0030740), the Industrial Strategic Technology Development Program (\#10079271), and the Korea Health Technology R\&D Project (No. HI14C2640).

\section{Competing interests}

The authors declare that they have no competing interests.

\section{Availability of data and materials}

The datasets generated or analyzed during the current study are available from the corresponding author on reasonable request.

\section{Consent for publication}

All authors consent to the publication of this manuscript.

\section{Ethics approval and consent to participate}

All patients or legal guardians consented to participation in the study in accordance with Institutional Review Board guidelines (IRB No. 1301-095-458). The human pancreatic cyst fluid samples were obtained from Seoul National University Hospital, South Korea.

\section{Publisher's Note}

Springer Nature remains neutral with regard to jurisdictional claims in published maps and institutional affiliations.

Received: 21 December 2017 Accepted: 4 April 2018

Published online: 18 April 2018

\section{References}

1. Andrejevic-Blant S, Kosmahl M, Sipos B, Kloppel G. Pancreatic intraductal papillary-mucinous neoplasms: a new and evolving entity. Virchows Arch. 2007:451:863-9.

2. Larghi A, Panic N, Capurso G, Leoncini E, Arzani D, Salvia R, Del Chiaro M, Frulloni L, Arcidiacono PG, Zerbi A, et al. Prevalence and risk factors of extrapancreatic malignancies in a large cohort of patients with intraductal papillary mucinous neoplasm (IPMN) of the pancreas. Ann Oncol. 2013;24:1907-11.

3. Hwang DW, Jang JY, Lee SE, Lim CS, Lee KU, Kim SW. Clinicopathologic analysis of surgically proven intraductal papillary mucinous neoplasms of the pancreas in SNUH: a 15-year experience at a single academic institution. Langenbecks Arch Surg. 2012;397:93-102.

4. Gourgiotis S, Ridolfini MP, Germanos S. Intraductal papillary mucinous neoplasms of the pancreas. Eur J Surg Oncol. 2007;33:678-84.

5. Tanaka M, Fernandez-del Castillo C, Adsay V, Chari S, Falconi M, Jang JY, Kimura W, Levy P, Pitman MB, Schmidt CM, et al. International consensus guidelines 2012 for the management of IPMN and MCN of the pancreas. Pancreatology. 2012;12:183-97.

6. Yip-Schneider MT, Wu H, Dumas RP, Hancock BA, Agaram N, Radovich M, Schmidt CM. Vascular endothelial growth factor, a novel and highly accurate pancreatic fluid biomarker for serous pancreatic cysts. J Am Coll Surg. 2014;218:608-17.

7. Carr RA, Yip-Schneider MT, Dolejs S, Hancock BA, Wu H, Radovich M, Schmidt CM. Pancreatic cyst fluid vascular endothelial growth factor A and carcinoembryonic antigen: a highly accurate test for the diagnosis of serous cystic neoplasm. J Am Coll Surg. 2017;225:93-100.

8. Jais B, Rebours V, Malleo G, Salvia R, Fontana M, Maggino L, Bassi C, Manfredi R, Moran R, Lennon AM, et al. Serous cystic neoplasm of the pancreas: a multinational study of 2622 patients under the auspices of the International Association of Pancreatology and European Pancreatic Club (European Study Group on Cystic Tumors of the Pancreas). Gut. 2016:65:305-12.

9. Horvath KD, Chabot JA. An aggressive resectional approach to cystic neoplasms of the pancreas. Am J Surg. 1999;178:269-74.

10. Ivry SL, Sharib JM, Dominguez DA, Roy N, Hatcher SE, Yip-Schneider MT, Schmidt CM, Brand RE, Park WG, Hebrok M, et al. Global protease activity profiling provides differential diagnosis of pancreatic cysts. Clin Cancer Res. 2017;23:4865-74.

11. Wu J, Matthaei H, Maitra A, Dal Molin M, Wood LD, Eshleman JR, Goggins M, Canto MI, Schulick RD, Edil BH, et al. Recurrent GNAS mutations define an unexpected pathway for pancreatic cyst development. Sci Transl Med. 2011;3:92ra66.

12. Khalid A, Zahid M, Finkelstein SD, LeBlanc JK, Kaushik N, Ahmad N, Brugge WR, Edmundowicz SA, Hawes RH, McGrath KM. Pancreatic cyst fluid DNA analysis in evaluating pancreatic cysts: a report of the PANDA study. Gastrointest Endosc. 2009;69:1095-102. 
13. Hezel AF, Kimmelman AC, Stanger BZ, Bardeesy N, Depinho RA. Genetics and biology of pancreatic ductal adenocarcinoma. Genes Dev. 2006;20:1218-49.

14. Almoguera C, Shibata D, Forrester K, Martin J, Arnheim N, Perucho M. Most human carcinomas of the exocrine pancreas contain mutant c-Kras genes. Cell. 1988;53:549-54.

15. Park WG, Mascarenhas R, Palaez-Luna M, SmyrkTC, O'Kane D, Clain JE, Levy MJ, Pearson RK, Petersen BT, Topazian MD, et al. Diagnostic performance of cyst fluid carcinoembryonic antigen and amylase in histologically confirmed pancreatic cysts. Pancreas. 2011;40:42-5.

16. Ke E, Patel BB, Liu T, Li XM, Haluszka O, Hoffman JP, Ehya H, Young NA, Watson JC, Weinberg DS, et al. Proteomic analyses of pancreatic cyst fluids. Pancreas. 2009;38:e33-42.

17. Bhutani MS, Gupta V, Guha S, Gheonea DI, Saftoiu A. Pancreatic cyst fluid analysis_-a review. J Gastrointestin Liver Dis. 2011;20:175-80.

18. Bassi C, Salvia R, Molinari E, Biasutti C, Falconi M, Pederzoli P. Management of 100 consecutive cases of pancreatic serous cystadenoma: wait for symptoms and see at imaging or vice versa? World I Surg. 2003;27:319-23.

19. Kehagias D, Smyrniotis V, Kalovidouris A, Gouliamos A, Kostopanagiotou E, Vassiliou J, Vlahos L. Cystic tumors of the pancreas: preoperative imaging, diagnosis, and treatment. Int Surg. 2002;87:171-4.

20. Hata T, Dal Molin M, Hong SM, Tamura K, Suenaga M, Yu J, Sedogawa H, Weiss MJ, Wolfgang CL, Lennon AM, et al. Predicting the grade of dysplasia of pancreatic cystic neoplasms using cyst fluid DNA methylation markers. Clin Cancer Res. 2017:23:3935-44.

21. Woolf KM, Liang H, Sletten ZJ, Russell DK, Bonfiglio TA, Zhou Z. Falsenegative rate of endoscopic ultrasound-guided fine-needle aspiration for pancreatic solid and cystic lesions with matched surgical resections as the gold standard: one institution's experience. Cancer Cytopathol. 2013;121:449-58

22. Thornton GD, McPhail MJ, Nayagam S, Hewitt MJ, Vlavianos P, Monahan KJ. Endoscopic ultrasound guided fine needle aspiration for the diagnosis of pancreatic cystic neoplasms: a meta-analysis. Pancreatology. 2013;13:48-57.

23. Maker AV, Carrara S, Jamieson NB, Pelaez-Luna M, Lennon AM, Dal Molin M, Scarpa A, Frulloni L, Brugge WR. Cyst fluid biomarkers for intraductal papillary mucinous neoplasms of the pancreas: a critical review from the international expert meeting on pancreatic branch-duct-intraductal papillary mucinous neoplasms. J Am Coll Surg. 2015;220:243-53.

24. Snozek CL, Mascarenhas RC, O'Kane DJ. Use of cyst fluid CEA, CA199 , and amylase for evaluation of pancreatic lesions. Clin Biochem. 2009:42:1585-8.

25. Frossard JL, Amouyal P, Amouyal G, Palazzo L, Amaris J, Soldan M, Giostra E, Spahr L, Hadengue A, Fabre M. Performance of endosonography-guided fine needle aspiration and biopsy in the diagnosis of pancreatic cystic lesions. Am J Gastroenterol. 2003;98:1516-24.

26. Amato E, Molin MD, Mafficini A, Yu J, Malleo G, Rusev B, Fassan M, Antonello D, Sadakari Y, Castelli P, et al. Targeted next-generation sequencing of cancer genes dissects the molecular profiles of intraductal papillary neoplasms of the pancreas. J Pathol. 2014;233:217-27.

27. Furukawa T, Kuboki Y, Tanji E, Yoshida S, Hatori T, Yamamoto M, Shibata N, Shimizu K, Kamatani N, Shiratori K. Whole-exome sequencing uncovers frequent GNAS mutations in intraductal papillary mucinous neoplasms of the pancreas. Sci Rep. 2011;1:161.

28. Poersch A, Sousa LO, Greene LJ, Faça VM, Reis F. Proteomic analysis of ovarian cancer tumor fluid is a rich source of potential biomarkers. J Proteomics Bioinform. 2014;11:225-37.

29. Schmidt A, Aebersold R. High-accuracy proteome maps of human body fluids. Genome Biol. 2006;7:242.

30. Yan W, Apweiler R, Balgley BM, Boontheung P, Bundy JL, Cargile BJ, Cole S, Fang X, Gonzalez-Begne M, Griffin TJ, et al. Systematic comparison of the human saliva and plasma proteomes. Proteomics Clin Appl. 2009;3:116-34.

31. Anderson NL, Anderson NG. The human plasma proteome: history, character, and diagnostic prospects. Mol Cell Proteomics. 2002;1:845-67.

32. Farina A. Proximal fluid proteomics for the discovery of digestive cancer biomarkers. Biochim Biophys Acta. 2014;1844:988-1002.
33. Talebian M, von Bartheld MB, Braun J, Versteegh MI, Dekkers OM, Rabe KF, Annema JT. EUS-FNA in the preoperative staging of non-small cell lung cancer. Lung Cancer. 2010;69:60-5.

34. Das KK, Xiao H, Geng X, Fernandez-Del-Castillo C, Morales-Oyarvide V, Daglilar E, Forcione DG, Bounds BC, Brugge WR, Pitman MB, et al. mAb Das-1 is specific for high-risk and malignant intraductal papillary mucinous neoplasm (IPMN). Gut. 2014:63:1626-34.

35. Ge PS, Gaddam S, Keach JW, Mullady D, Fukami N, Edmundowicz SA, Azar RR, Shah RJ, Murad FM, Kushnir VM, et al. Predictors for surgical referral in patients with pancreatic cystic lesions undergoing endoscopic ultrasound: results from a large multicenter cohort study. Pancreas. 2016;45:51-7.

36. Cuoghi A, Farina A, Z'Graggen $K$, Dumonceau JM, Tomasi A, Hochstrasser DF, Genevay M, Lescuyer P, Frossard JL. Role of proteomics to differentiate between benign and potentially malignant pancreatic cysts. J Proteome Res. 2011;10:2664-70.

37. Gbormittah FO, Haab BB, Partyka K, Garcia-Ott C, Hancapie M, Hancock WS. Characterization of glycoproteins in pancreatic cyst fluid using a high-performance multiple lectin affinity chromatography platform. J Proteome Res. 2014;13:289-99.

38. Park J, Han D, Do M, Woo J, Wang Jl, Han Y, Kwon W, Kim SW, Jang $J$ Y, Kim Y. Proteome characterization of human pancreatic cyst fluid from intraductal papillary mucinous neoplasm by liquid chromatography/tandem mass spectrometry. Rapid Commun Mass Spectrom. 2017;31:1761-72.

39. Wisniewski JR, Mann M. Consecutive proteolytic digestion in an enzyme reactor increases depth of proteomic and phosphoproteomic analysis. Anal Chem. 2012;84:2631-7.

40. Han D, Moon S, Kim Y, Min H, Kim Y. Characterization of the membrane proteome and $\mathrm{N}$-glycoproteome in BV-2 mouse microglia by liquid chromatography-tandem mass spectrometry. BMC Genom. 2014;15:95.

41. Wisniewski JR, Gaugaz FZ. Fast and sensitive total protein and peptide assays for proteomic analysis. Anal Chem. 2015;87:4110-6.

42. Rappsilber J, Mann M, Ishihama Y. Protocol for micro-purification, enrichment, pre-fractionation and storage of peptides for proteomics using StageTips. Nat Protoc. 2007;2:1896-906.

43. Han D, Jin J, Woo J, Min H, Kim Y. Proteomic analysis of mouse astrocytes and their secretome by a combination of FASP and StageTip-based, high pH, reversed-phase fractionation. Proteomics. 2014;14:1604-9.

44. Han D, Moon S, Kim Y, Kim J, Jin J, Kim Y. In-depth proteomic analysis of mouse microglia using a combination of FASP and StageTip-based, high pH, reversed-phase fractionation. Proteomics. 2013;13:2984-8.

45. Woo J, Han D, Park J, Kim SJ, Kim Y. In-depth characterization of the secretome of mouse CNS cell lines by LC-MS/MS without prefractionation. Proteomics. 2015;15:3617-22.

46. Cox J, Mann M. MaxQuant enables high peptide identification rates, individualized p.p.b.-range mass accuracies and proteome-wide protein quantification. Nat Biotechnol. 2008;26:1367-72.

47. Elias JE, Gygi SP. Target-decoy search strategy for increased confidence in large-scale protein identifications by mass spectrometry. Nat Methods. 2007:4:207-14.

48. Nesvizhskii Al, Keller A, Kolker E, Aebersold R. A statistical model for identifying proteins by tandem mass spectrometry. Anal Chem. 2003;75:4646-58.

49. Zhang B, Chambers MC, Tabb DL. Proteomic parsimony through bipartite graph analysis improves accuracy and transparency. J Proteome Res. 2007;6:3549-57.

50. Nesvizhskii Al, Aebersold R. Interpretation of shotgun proteomic data: the protein inference problem. Mol Cell Proteomics. 2005;4:1419-40.

51. Vizcaino JA, Cote RG, Csordas A, Dianes JA, Fabregat A, Foster JM, Griss J, Alpi E, Birim M, Contell J, et al. The PRoteomics IDEntifications (PRIDE) database and associated tools: status in 2013. Nucleic Acids Res. 2013;41:D1063-9.

52. Vizcaino JA, Deutsch EW, Wang R, Csordas A, Reisinger F, Rios D, Dianes JA, Sun Z, Farrah T, Bandeira N, et al. ProteomeXchange provides globally coordinated proteomics data submission and dissemination. Nat Biotechnol. 2014;32:223-6.

53. Cox J, Hein MY, Luber CA, Paron I, Nagaraj N, Mann M. Accurate proteome-wide label-free quantification by delayed normalization and 
maximal peptide ratio extraction, termed MaxLFQ. Mol Cell Proteomics. 2014;13:2513-26.

54. Muthusamy B, Hanumanthu G, Suresh S, Rekha B, Srinivas D, Karthick L, Vrushabendra BM, Sharma S, Mishra G, Chatterjee P, et al. Plasma proteome database as a resource for proteomics research. Proteomics. 2005:5:3531-6.

55. Nanjappa V, Thomas JK, Marimuthu A, Muthusamy B, Radhakrishnan A, Sharma R, Ahmad Khan A, Balakrishnan L, Sahasrabuddhe NA, Kumar S, et al. Plasma proteome database as a resource for proteomics research: 2014 update. Nucleic Acids Res. 2014;42:D959-65.

56. Chebib I, Yaeger K, Mino-Kenudson M, Pitman MB. The role of cytopathology and cyst fluid analysis in the preoperative diagnosis and management of pancreatic cysts $>3 \mathrm{~cm}$. Cancer Cytopathol. 2014;122:804-9.

57. Tanaka M, Chari S, Adsay V, Fernandez-del Castillo C, Falconi M, Shimizu M, Yamaguchi K, Yamao K, Matsuno S. International Association of P: International consensus guidelines for management of intraductal papillary mucinous neoplasms and mucinous cystic neoplasms of the pancreas. Pancreatology. 2006;6:17-32.

58. Sahora K, Mino-Kenudson M, Brugge W, Thayer SP, Ferrone CR, Sahani D, Pitman MB, Warshaw AL, Lillemoe KD, Fernandez-del Castillo CF. Branch duct intraductal papillary mucinous neoplasms: does cyst size change the tip of the scale? A critical analysis of the revised international consensus guidelines in a large single-institutional series. Ann Surg. 2013;258:466-75

59. Han Y, Lee H, Kang JS, Kim JR, Kim HS, Lee JM, Lee KB, Kwon W, Kim SW, Jang JY. Progression of pancreatic branch duct intraductal papillary mucinous neoplasm associates with cyst size. Gastroenterology. 2017:154:576-84.

60. Oh JH, Wong HP, Wang X, Deasy JO. A bioinformatics filtering strategy for identifying radiation response biomarker candidates. PLOS ONE. 2012; $7:$ e38870.

61. Sharma K, Schmitt S, Bergner CG, Tyanova S, Kannaiyan N, ManriqueHoyos N, Kongi K, Cantuti L, Hanisch UK, Philips MA, et al. Cell typeand brain region-resolved mouse brain proteome. Nat Neurosci. 2015;18:1819-31.

62. Azimifar SB, Nagaraj N, Cox J, Mann M. Cell-type-resolved quantitative proteomics of murine liver. Cell Metab. 2014;20:1076-87.

63. Schwartz EB, Granger DA. Transferrin enzyme immunoassay for quantitative monitoring of blood contamination in saliva. Clin Chem. 2004;50:654-6.

64. Aasebo E, Opsahl JA, Bjorlykke Y, Myhr KM, Kroksveen AC, Berven FS. Effects of blood contamination and the rostro-caudal gradient on the human cerebrospinal fluid proteome. PLoS ONE. 2014;9:e90429.

65. Martinez-Garcia E, Lesur A, Devis L, Campos A, Cabrera S, van Oostrum J, Matias-Guiu X, Gil-Moreno A, Reventos J, Colas E, Domon B. Development of a sequential workflow based on LC-PRM for the verification of endometrial cancer protein biomarkers in uterine aspirate samples. Oncotarget. 2016;7:53102-15.

66. Chung YT, Matkowskyj KA, Li H, Bai H, Zhang W, Tsao MS, Liao J, Yang GY. Overexpression and oncogenic function of aldo-keto reductase family 1 B10 (AKR1B10) in pancreatic carcinoma. Mod Pathol. 2012;25:758-66

67. Zhu J, Thakolwiboon S, Liu X, Zhang M, Lubman DM. Overexpression of CD90 (Thy-1) in pancreatic adenocarcinoma present in the tumor microenvironment. PLoS ONE. 2014:9:e115507.

68. Hosokawa M, Kashiwaya K, Eguchi H, Ohigashi H, Ishikawa O, Furihata M, Shinomura Y, Imai K, Nakamura Y, Nakagawa H. Over-expression of cysteine proteinase inhibitor cystatin 6 promotes pancreatic cancer growth. Cancer Sci. 2008;99:1626-32.

69. Yonezawa S, Horinouchi M, Osako M, Kubo M, Takao S, Arimura Y, Nagata K, Tanaka S, Sakoda K, Aikou T, Sato E. Gene expression of gastric type mucin (MUC5AC) in pancreatic tumors: its relationship with the biological behavior of the tumor. Pathol Int. 1999:49:45-54.

70. Yonezawa S, Higashi M, Yamada N, Goto M. Precursor lesions of pancreatic cancer. Gut Liver. 2008;2:137-54

71. Sopha SC, Gopal P, Merchant NB, Revetta FL, Gold DV, Washington K, Shi C. Diagnostic and therapeutic implications of a novel immunohistochemical panel detecting duodenal mucosal invasion by pancreatic ductal adenocarcinoma. Int J Clin Exp Pathol. 2013;6:2476-86.
72. Jinfeng M, Kimura W, Hirai I, Sakurai F, Moriya T, Mizutani M. Expression of MUC5AC and MUC6 in invasive ductal carcinoma of the pancreas and relationship with prognosis. Int J Gastrointest Cancer. 2003;34:9-18.

73. Distler M, Kersting S, Niedergethmann M, Aust DE, Franz M, Ruckert F, Ehehalt F, Pilarsky C, Post S, Saeger HD, Grutzmann R. Pathohistological subtype predicts survival in patients with intraductal papillary mucinous neoplasm (IPMN) of the pancreas. Ann Surg. 2013;258:324-30.

74. Michiko Horinouchi KN, Nakamura A, Goto M, Takao S, Sakamoto M, Fukushima N, Miwa A, Irimura T, Imai K, Sato E, Yonezawa S. Expression of different glycoforms of membrane mucin (MUC1) and secretory mucin (MUC2, MUC5AC and MUC6) in pancreatic neoplasms. Acta Histochem Cytochem. 2003;36:443-53.

75. Arumugam T, Brandt W, Ramachandran V, Moore TT, Wang H, May FE, Westley BR, Hwang RF, Logsdon CD. Trefoil factor 1 stimulates both pancreatic cancer and stellate cells and increases metastasis. Pancreas. 2011;40:815-22.

76. Collier JD, Bennett MK, Bassendine MF, Lendrum R. Immunolocalization of pS2, a putative growth factor, in pancreatic carcinoma. J Gastroenterol Hepatol. 1995;10:396-400.

77. Ebert MP, Hoffmann J, Haeckel C, Rutkowski K, Schmid RM, Wagner M, Adler G, Schulz HU, Roessner A, Hoffmann W, Malfertheiner P. Induction ofTFF1 gene expression in pancreas overexpressing transforming growth factor alpha. Gut. 1999;45:105-11.

78. Kirby RE, Lewandrowski KB, Southern JF, Compton CC, Warshaw AL. Relation of epidermal growth factor receptor and estrogen receptorindependent pS2 protein to the malignant transformation of mucinous cystic neoplasms of the pancreas. Arch Surg. 1995;130:69-72.

79. Radon TP, Massat NJ, Jones R, Alrawashdeh W, Dumartin L, Ennis D, Duffy SW, Kocher HM, Pereira SP, Guarner Posthumous L, et al. Identification of a three-biomarker panel in urine for early detection of pancreatic adenocarcinoma. Clin Cancer Res. 2015;21:3512-21.

80. Wolf WC, Harley RA, Sluce D, Chao L, Chao J. Cellular localization of kallistatin and tissue kallikrein in human pancreas and salivary glands. Histochem Cell Biol. 1998;110:477-84.

81. Huang T, Jiang SW, Qin L, Senkowski C, Lyle C, Terry K, Brower S, Chen $\mathrm{H}$, Glasgow W, Wei Y, Li J. Expression and diagnostic value of HE4 in pancreatic adenocarcinoma. Int J Mol Sci. 2015;16:2956-70.

82. Galgano MT, Hampton GM, Frierson HF Jr. Comprehensive analysis of HE4 expression in normal and malignant human tissues. Mod Pathol. 2006;19:847-53.

83. O'Neal RL, Nam KT, LaFleur BJ, Barlow B, Nozaki K, Lee HJ, Kim WH, Yang HK, Shi C, Maitra A, et al. Human epididymis protein 4 is up-regulated in gastric and pancreatic adenocarcinomas. Hum Pathol. 2013;44:734-42.

84. Sanada Y, Hirose Y, Osada S, Tanaka Y, Takahashi T, Yamaguchi K, Yoshida K. Immunohistochemical study of claudin 18 involvement in intestinal differentiation during the progression of intraductal papillary mucinous neoplasm. Anticancer Res. 2010;30:2995-3003.

85. Soini Y, Takasawa A, Eskelinen M, Juvonen P, Karja V, Hasegawa T, Murata M, Tanaka S, Kojima T, Sawada N. Expression of claudins 7 and 18 in pancreatic ductal adenocarcinoma: association with features of differentiation. J Clin Pathol. 2012:65:431-6.

86. Garcia-Hernandez V, Sarmiento N, Sanchez-Bernal C, Matellan L, Calvo $\mathrm{JJ}$, Sanchez-Yague J. Modulation in the expression of SHP-1, SHP-2 and PTP1B due to the inhibition of MAPKs, CAMP and neutrophils early on in the development of cerulein-induced acute pancreatitis in rats. Biochim Biophys Acta. 2014;1842:192-201.

87. Shinkai K, Nakano K, Cui L, Mizuuchi Y, Onishi H, Oda Y, Obika S, Tanaka M, Katano M. Nuclear expression of Y-box binding protein-1 is associated with poor prognosis in patients with pancreatic cancer and its knockdown inhibits tumor growth and metastasis in mice tumor models. Int J Cancer. 2016;139:433-45.

88. Takao S, Takebayashi Y, Che X, Shinchi H, Natsugoe S, Miyadera K, Yamada Y, Akiyama S, Aikou T. Expression of thymidine phosphorylase is associated with a poor prognosis in patients with ductal adenocarcinoma of the pancreas. Clin Cancer Res. 1998;4:1619-24.

89. Nishida Y, Aida K, Kihara M, Kobayashi T. Antibody-validated proteins in inflamed islets of fulminant type 1 diabetes profiled by lasercapture microdissection followed by mass spectrometry. PLOS ONE. 2014;9:e107664. 
90. Prohaska TA, Wahlmuller FC, Furtmuller M, Geiger M. Interaction of protein $C$ inhibitor with the type II transmembrane serine protease enteropeptidase. PLoS ONE. 2012;7:e39262.

91. Naba A, Clauser KR, Mani DR, Carr SA, Hynes RO. Quantitative proteomic profiling of the extracellular matrix of pancreatic islets during the angiogenic switch and insulinoma progression. Sci Rep. 2017;7:40495.

92. Lee JH, Kim KS, Kim TJ, Hong SP, Song SY, Chung JB, Park SW. Immunohistochemical analysis of claudin expression in pancreatic cystic tumors. Oncol Rep. 2011;25:971-8.

93. Tanaka M, Shibahara J, Fukushima N, Shinozaki A, Umeda M, Ishikawa S, Kokudo N, Fukayama M. Claudin-18 is an early-stage marker of pancreatic carcinogenesis. J Histochem Cytochem. 2011;59:942-52.

94. Karanjawala ZE, IIlei PB, Ashfaq R, Infante JR, Murphy K, Pandey A, Schulick R, Winter J, Sharma R, Maitra A, et al. New markers of pancreatic cancer identified through differential gene expression analyses: claudin 18 and annexin A8. Am J Surg Pathol. 2008;32:188-96.

95. Douziech N, Calvo E, Coulombe Z, Muradia G, Bastien J, Aubin RA, Lajas A, Morisset J. Inhibitory and stimulatory effects of somatostatin on two human pancreatic cancer cell lines: a primary role for tyrosine phosphatase SHP-1. Endocrinology. 1999;140:765-77.

96. Sarmiento N, Sanchez-Bernal C, Ayra M, Perez N, Hernandez-Hernandez A, Calvo JJ, Sanchez-Yague J. Changes in the expression and dynamics of SHP-1 and SHP-2 during cerulein-induced acute pancreatitis in rats. Biochim Biophys Acta. 2008;1782:271-9.

97. Blackberg M, Berling R, Ohlsson K. Tissue kallikrein in severe acute pancreatitis in patients treated with high-dose intraperitoneal aprotinin Pancreas. 1999:19:325-34.

98. Ferreira AR, Bettencourt M, Alho I, Costa AL, Sousa AR, Mansinho A, Abreu C, Pulido C, Macedo D, Vendrell I, et al. Serum YB-1 (Y-box binding protein 1) as a biomarker of bone disease progression in patients with breast cancer and bone metastases. J Bone Oncol. 2017;6:16-21.

99. Zhao S, Guo W, Li J, Yu W, Guo T, Deng W, Gu C. High expression of Y-box-binding protein 1 correlates with poor prognosis and early recurrence in patients with small invasive lung adenocarcinoma. Onco Targets Ther. 2016;9:2683-92.

100. Miao X, Wu Y, Wang Y, Zhu X, Yin H, He Y, Li C, Liu Y, Lu X, Chen Y, et al. Y-box-binding protein-1 (YB-1) promotes cell proliferation, adhesion and drug resistance in diffuse large B-cell lymphoma. Exp Cell Res. 2016;346:157-66.

101. O'Brien TS, Fox SB, Dickinson AJ, Turley H, Westwood M, Moghaddam A, Gatter KC, Bicknell R, Harris AL. Expression of the angiogenic factor thymidine phosphorylase/platelet-derived endothelial cell growth factor in primary bladder cancers. Cancer Res. 1996;56:4799-804.

102. Li J, Chen H, Curcuru JR, Patel S, Johns TO, Patel D, Qian H, Jiang SW. Serum HE4 level as a biomarker to predict the recurrence of gynecologic cancers. Curr Drug Targets. 2017;18:1158-64.

103. Hellstrom I, Raycraft J, Hayden-Ledbetter M, Ledbetter JA, Schummer M, McIntosh M, Drescher C, Urban N, Hellstrom KE. The HE4 (WFDC2) protein is a biomarker for ovarian carcinoma. Cancer Res. 2003;63:3695-700.

104. Ishibashi Y, Ohtsu H, Ikemura M, Kikuchi Y, Niwa T, Nishioka K, Uchida Y, Miura H, Aikou S, Gunji T, et al. Serum TFF1 and TFF3 but not TFF2 are higher in women with breast cancer than in women without breast cancer. Sci Rep. 2017;7:4846.

105. Zhang DH, Yang ZL, Zhou EX, Miao XY, Zou Q, Li JH, Liang LF, Zeng GX, Chen SL. Overexpression of Thy 1 and ITGA6 is associated with invasion, metastasis and poor prognosis in human gallbladder carcinoma. Oncol Lett. 2016;12:5136-44.

106. Yoshitake H, Takahashi M, Ishikawa H, Nojima M, Iwanari H, Watanabe A, Aburatani H, Yoshida K, Ishi K, Takamori K, et al. Aldo-keto reductase family 1, member B10 in uterine carcinomas: a potential risk factor of recurrence after surgical therapy in cervical cancer. Int J Gynecol Cancer. 2007;17:1300-6.

107. Heringlake S, Hofdmann M, Fiebeler A, Manns MP, Schmiegel W, Tannapfel A. Identification and expression analysis of the aldo-ketoreductase1-B10 gene in primary malignant liver tumours. J Hepatol. 2010;52:220-7.

108. Fukumoto S, Yamauchi N, Moriguchi H, Hippo Y, Watanabe A, Shibahara J, Taniguchi H, Ishikawa S, Ito H, Yamamoto S, et al. Overexpression of the aldo-keto reductase family protein AKR1B10 is highly correlated with smokers' non-small cell lung carcinomas. Clin Cancer Res. 2005; 11:1776-85.

109. He X, Zhu Z, Johnson C, Stoops J, Eaker AE, Bowen W, DeFrances MC. PIK3IP1, a negative regulator of PI3 K, suppresses the development of hepatocellular carcinoma. Cancer Res. 2008;68:5591-8.

110. Wang Z, Liu Y, Lu L, Yang L, Yin S, Wang Y, Qi Z, Meng J, Zang R, Yang G. Fibrillin-1, induced by Aurora-A but inhibited by BRCA2, promotes ovarian cancer metastasis. Oncotarget. 2015;6:6670-83.

111. Cierna Z, Mego M, Jurisica I, Machalekova K, Chovanec M, Miskovska V, Svetlovska D, Kalavska K, Rejlekova K, Kajo K, et al. Fibrillin-1 (FBN-1) a new marker of germ cell neoplasia in situ. BMC Cancer. 2016;16:597.

112. Wakita T, Hayashi T, Nishioka J, Tamaru H, Akita N, Asanuma K, Kamada H, Gabazza EC, Ido M, Kawamura J, Suzuki K. Regulation of carcinoma cell invasion by protein C inhibitor whose expression is decreased in renal cell carcinoma. Int J Cancer. 2004;108:516-23.

113. Jing Y, Jia D, Wong CM, Oi-Lin Ng I, Zhang Z, Liu L, Wang Q, Zhao F, Li J, Yao M, et al. SERPINA5 inhibits tumor cell migration by modulating the fibronectin-integrin beta1 signaling pathway in hepatocellular carcinoma. Mol Oncol. 2014;8:366-77.

114. Cao Y, Becker C, Lundwall A, Christensson A, Gadaleanu V, Lilja H, Bjartell A. Expression of protein $\mathrm{C}$ inhibitor (PCI) in benign and malignant prostatic tissues. Prostate. 2003;57:196-204.

115. Bijsmans IT, Smits KM, de Graeff P, Wisman GB, van der Zee AG, Slangen $B F$, de Bruine AP, van Engeland M, Sieben NL, Van de Vijver KK. Loss of SerpinA5 protein expression is associated with advanced-stage serous ovarian tumors. Mod Pathol. 2011;24:463-70.

116. Zhang JL, Qian YB, Zhu LX, Xiong QR. Talin1, a valuable marker for diagnosis and prognostic assessment of human hepatocelluar carcinomas. Asian Pac J Cancer Prev. 2011;12:3265-9.

117. Xu YF, Ren XY, Li YQ, He QM, Tang XR, Sun Y, Shao JY, Jia WH, Kang TB, Zeng MS, et al. High expression of Talin-1 is associated with poor prognosis in patients with nasopharyngeal carcinoma. BMC Cancer. 2015;15:332.

118. Xu N, Chen HJ, Chen SH, Xue XY, Chen H, Zheng QS, Wei Y, Li XD, Huang $J B$, Cai H, Sun XL. Upregulation of Talin-1 expression associates with advanced pathological features and predicts lymph node metastases and biochemical recurrence of prostate cancer. Medicine (Baltimore). 2016:95:e4326.

119. Lai MT, Hua CH, Tsai MH, Wan L, Lin YJ, Chen CM, Chiu IW, Chan C, Tsai FJ, Jinn-Chyuan Sheu J. Talin-1 overexpression defines high risk for aggressive oral squamous cell carcinoma and promotes cancer metastasis. J Pathol. 2011;224:367-76.

120. Bubnov V, Moskalev E, Petrovskiy Y, Bauer A, Hoheisel J, Zaporozhan V. Hypermethylation of TUSC 5 genes in breast cancer tissue. Exp Oncol. 2012;34:370-2.

121. Sun X, Zhang Q, Chen W, Hu Q, Lou Y, Fu QH, Zhang JY, Chen YW, Ye LY, Wang Y, et al. Hook1 inhibits malignancy and epithelialmesenchymal transition in hepatocellular carcinoma. Tumour Biol. 2017;39:1010428317711098.

122. Dinets A, Pernemalm M, Kjellin H, Sviatoha V, Sofiadis A, Juhlin CC, Zedenius J, Larsson C, Lehtio J, Hoog A. Differential protein expression profiles of cyst fluid from papillary thyroid carcinoma and benign thyroid lesions. PLoS ONE. 2015;10:e0126472.

123. Romero-Calvo I, Ocon B, Martinez-Moya P, Suarez MD, Zarzuelo A, Martinez-Augustin O, de Medina FS. Reversible Ponceau staining as a loading control alternative to actin in Western blots. Anal Biochem. 2010;401:318-20.

124. Yang T, Xu F, Xu J, Fang D, Yu Y, Chen Y. Comparison of liquid chromatography-tandem mass spectrometry-based targeted proteomics and conventional analytical methods for the determination of P-glycoprotein in human breast cancer cells. J Chromatogr B Analyt Technol Biomed Life Sci. 2013;936:18-24.

125. Whelan SA, He J, Lu M, Souda P, Saxton RE, Faull KF, Whitelegge JP, Chang HR. Mass spectrometry (LC-MS/MS) identified proteomic biosignatures of breast cancer in proximal fluid. J Proteome Res. 2012:11:5034-45.

126. Suh EJ, Kabir MH, Kang UB, Lee JW, Yu J, Noh DY, Lee C. Comparative profiling of plasma proteome from breast cancer patients reveals thrombospondin-1 and BRWD3 as serological biomarkers. Exp Mol Med. 2012;44:36-44. 
127. Molina H, Yang Y, Ruch T, Kim JW, Mortensen P, Otto T, Nalli A, Tang QQ, Lane MD, Chaerkady R, Pandey A. Temporal profiling of the adipocyte proteome during differentiation using a five-plex SILAC based strategy. J Proteome Res. 2009;8:48-58.

128. Liebler DC, Zimmerman LJ. Targeted quantitation of proteins by mass spectrometry. Biochemistry. 2013;52:3797-806.

129. Aebersold R, Burlingame AL, Bradshaw RA. Western blots versus selected reaction monitoring assays: time to turn the tables? Mol Cell Proteomics. 2013;12:2381-2.
130. Towbin H, Staehelin T, Gordon J. Electrophoretic transfer of proteins from polyacrylamide gels to nitrocellulose sheets: procedure and some applications. Proc Natl Acad Sci USA. 1979;76:4350-4.

131. Geyer PE, Holdt LM, Teupser D, Mann M. Revisiting biomarker discovery by plasma proteomics. Mol Syst Biol. 2017;13:942

132. Hoofnagle AN, Wener MH. The fundamental flaws of immunoassays and potential solutions using tandem mass spectrometry. J Immunol Methods. 2009;347:3-11.
Ready to submit your research? Choose BMC and benefit from:

- fast, convenient online submission

- thorough peer review by experienced researchers in your field

- rapid publication on acceptance

- support for research data, including large and complex data types

- gold Open Access which fosters wider collaboration and increased citations

- maximum visibility for your research: over $100 \mathrm{M}$ website views per year

At BMC, research is always in progress.

Learn more biomedcentral.com/submissions 